\title{
Traditionalist Sufism: Outlining the Foundations of the Journey
}

\section{Introduction}

In this chapter we commence with a study of al-Wāsițîs method of sulūk by expounding upon a set of recurring elements in his writings that we may identify as its foundations. Although I do not mean to claim that this endeavor will convey the full spectrum of the foundations of Sufism as he envisioned it, I believe that the themes we will focus on were, in his view, essential to the further continuation on the pathway towards God. It is those elements that can either make or break one's sulūk, so to speak. Whatever the sālik seeks to attain through Sufism without them, or with a faulty understanding of them, will prove fruitless in his view.

This chapter is divided into three sections. The first of these deals with knowledge of the Prophet, the second with knowledge of God. These two sections very much stand together as consecutive steps that are supposed to firmly set the sālik on his path. The third section is concerned with al-Wāsiṭ̂'s negative definition of Sufism. It aims to give an overview of the polemical side of his writings, by which he intended to provide a solid argumentation against practices and doctrines that he felt will thwart the sālik's journey. We will thus find that the foundations of Sufism are not only defined in terms of what constitutes the correct path, that is, 'selfing,' but also in terms of what leads astray from it, that is, 'othering.'

I will argue that the common thread that connects each of the subjects under consideration is traditionalism. Even when we can clearly distinguish alWāsițīs own creative thought at work, he was, in his own mind, constantly anchored in the scholarly tradition of the Ahl al-Hadith. For as he saw it, to deviate from it would be to deviate from the pure path of the righteous predecessors, the Salaf. As we have seen, he held that out of all Muslim fractions that have come into existence since the beginning of Islam, only the traditionalists continued to represent the true Ahl al-Sunna wa-al-Jamā'a. And as many traditionalists had done before him, he regularly reminds us in his corpus that this title belongs solely to the partisans of hadith by rendering it as 'Ahl alSunna wa-al-Hadith,' and various other modifications of the label, in order to 
emphasize that to be a Sunni Muslim is to be a traditionalist. ${ }^{1}$ Moreover, he often buttresses his school's authority by counting amongst its ranks such early renowned scholars as Mālik b. Anas (d. 179/795), 'Abd Allāh b. al-Mubārak (d. 181/797), Ibn Idrīs al-Shāfiī (d. 204/819-820), Aḥmad Ibn Ḥanbal (d. 241/855), and the well-known compilers of hadìth collections, such as al-Bukhārī (d. 256/870) and Muslim (d. 261/875). ${ }^{2}$ By laying claim to such figures, he effectively presents the Ahlal-Hadith movement as the sole representatives of their legacy - or rather, the legacy of the Prophet, which they conveyed most soundly.

When it comes to the way he defined the foundations of Sufism, the current chapter will demonstrate that he very explicitly aimed to build on a traditionalist basis. Each of the following three sections will illustrate how this is apparent in his teachings. We will first and foremost draw attention to his reliance on the nușuss, the Qur'an and the Sunna, as the primary sources of spiritual knowledge, and to his use of traditionalist hermeneutics to understand them. Secondly, we will occasionally point to instances of overlap between him and Ibn Taymiyya, not to prove that al-Wāsițîs teachings were directly influenced by his shaykh per se, but rather to highlight that both scholars appear to have operated within the same traditionalist framework. Finally, the third section will demonstrate how al-Wāsițī worked from a traditionalist framework to exclude from Sufism those Sufis whom he polemicized against.

\section{The Muhammadan Way (al-Tarīqa al-Muḥammadiyya)}

He said: "The Lord came from Sinai, and dawned over them from Seir;

He shone forth from Mount Paran."

(Book of Deuteronomy: 33:2)

These words from the Torah and the Old Testament are quoted in Arabic in alWāsițìs Talqīh al-asrār, where he comments that the first line is an allusion to the coming of Moses, the second to the coming of Jesus, and the third to the

1 Al-Wāsițī, Risalatuhu ilā al-shaykh al-Maghribī, p. 108; other variations of the label al-Wāsițī mentions are: 'Ahl al-Hadith wa-al-Sunna,' 'Ahl al-Sunna wa-al-Athar,' and 'Ahl al-Sunna wa-

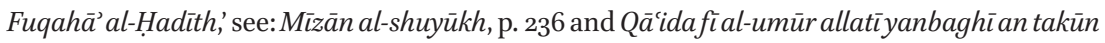
hamm al-sālik, p. 192.

2 Al-Wāsițī, Madkhal ahl al-figh, p. 51; Risāla fì ithbāt, p. 40; Qāंida fì taşfiyyat al-akhlāq, p. 93; Qā'ida fì al-umūr allatì yanbaghì an takūn hamm al-sālik, p. 192; 'Umdat al-țullāb, p. 202; Risālatuhu ilā al-shaykh al-Maghribì, p. 108. 
coming of Muhammad. ${ }^{3}$ He will undoubtedly have taken this interpretation from 'the Proofs of Prophethood' (daläil al-nubuwwa), one of the subcategories of literature on the Prophet Muhammad into which he had immersed himself. As we have seen in the previous chapter, he took this direction under the guidance of Ibn Taymiyya. However, we have yet to see the far-reaching impact that this had on his spiritual life. In the current section we will explore the result of his endeavor to formulate a form of Sufism in which the Prophet is allotted a central role. As we shall see, one of the primary foundations of Sufism he describes is centered around acquainting oneself with the Prophet and, eventually, establishing a relationship with him.

\subsection{The Origins of the Țarīqa Muhammadiyya}

From the perspective of our Iraqi Sufi, true Sufism was nothing other than the pure inward dimension - the ba țin - of the Prophet Muhammad's Sunna. He sometimes conceptualizes his method of sulūk as the Muhammadan way (altariqa al-Muhammadiyya), ${ }^{4}$ the guidance of the Muhammadan light (al-nūr al-Muhammadī $),{ }^{5}$ and the path of Muhammadan poverty (taríqat al-faqr alMuhammadī). ${ }^{6}$ To characterize the effects of this particular path as opposed to the paths of those Sufis whom he rejects for straying from it, he occasionally likes to use Sufi terminology with the adjective 'Muhammadi added to it. He speaks, for instance, of the Muhammadan taste (al-dhawq al-Muhammadī $)^{7}$ and the Muhammadan state (al-hâal al-Muhammadī). ${ }^{8}$ As we will see, he was thereby separating himself from other trends of Sufism that were at variance with the principles of traditionalism he adhered to. ${ }^{9}$ His writings convey again and again that to deviate from the path of the Ahl al-Hadith is to deviate from the Muhammadan way.

3 Al-Wāsițī, Talqịh al-asrār, p. 54.

4 Al-Wāsițī, Qā'ida fì bayān 'amal yawm wa-layla li-al-abrār, p. 27; Qā'ida fí aṣnāf al-ta’alluh, p. 151; and in the title of his Miftāh al-márifa wa-al-ibāda li-ahl al-țalab wa-al-irāda al-rāghibìn fì al-dukhūl ilā dār al-sa'āda min al-țarīqa al-muhammadiyya allatī laysat munharifat ${ }^{a n}$ 'an al-jädda (The key to intimate knowledge and worship for those who seek and desire [God], who wish to enter the Abode of Happiness through the Muhammadan way, which never deviates from the right course).

5 'Umdat al-țullāb, p. 198; al-Tadhkira, p. 40.

6 al-Wāsițī, Qã'ida mukhtașara fì țarīq al-faqr 'alā minhāj al-rasūl; the whole treatise is about Muhammadan poverty, which is referred to as a distinct țariqa, or path, on p. 25. In his Mìzān al-shuyükh, p. 247, he explains that spiritual poverty, or faqr, signifies the effort to remain constantly connected to the Prophet and to God.

7 Al-Wāsițī, Qā'ida fíașnāf al-ta’alluh, pp. 153-154; al-Bulgha, f. 69 a.

8 Al-Wāsițī, Qã ida fíașnāf al-ta’alluh, p. 153; Qā'ida tatimma li-hādhihi al-qā'ida fì al-ta'alluhāt, p. 156 .

9 A similar observation was made by Geoffroy, "Le traité de soufisme," p. 95. 
In the field of Sufi studies, the term 'taríqa Muhammadizya' is mostly known as a concept that is characteristic of a distinct type of reformist Sufi movement that emerged during the late eighteenth and early nineteenth century, which scholars have referred to as neo-Sufism. Bruce B. Lawrence, for instance, has observed that

the nineteenth century witnessed a more explicit, and more openly public, awareness of the Prophet as the crucial link between God and humankind. It has been etched in the phrase al-tarīqa al-Muhammadiyya. What underlies al-tariq a al-Muhammadiyya ... is not just loyalty to the Prophet but connection to his reality (al-haqiqa al-Muhammadiyya) and to his light (al-nūr al-Muhammadī)..$^{10}$

The 'Muhammadan way' as a Sufi concept with a much longer history has already been established by Vincent J. Cornell, who thought to have found "the apparent originator of the term" in 'Abd Allāh al-Ghazwānì (d. 935/1528-1529), a Moroccan Sufi shaykh of the Jazūliyya order. ${ }^{11}$ The latter coined it as the title for his doctrine that based the "authority of the Sufi shaykh ... on an explicit analogy between the saint and the Prophet Muhammad."12 Evidently, the term actually goes back at least two more centuries before al-Ghazwānī, as it can be found in the writings of al-Wāsiți and, perhaps surprisingly, also in those of Ibn Taymiyya.

FritzMeieralreadynoted thatIbn Taymiyya coined the term 'Muhammadiyya,' and overlooked that he actually used the term 'țariqa Muhammadiyya' as well. Ibn Taymiyya adopts it in two treatises as something of an umbrella term for

$10 \quad$ Bruce B. Lawrence, "Sufism and neo-Sufism," in The New Cambridge History of Islam Volume 6, ed. R. Hefner (Cambridge: Cambridge University Press, 2010), p. 356, where he specifically identifies the concept with the North African movement of Muhammad alSanūsī (d. 1859) and the north Indian movement of Sayyid Ahmmad Barelwī (d. 1831). Note that the early proponents of the neo-Sufism theory have mistakenly understood the țariqa Muhammadiyya as an effort to develop a concept of union with the Prophet in order to replace the concept of union with God. This understanding has been criticized by Rex S. O'Fahey \& Bernd Radtke, "Neo-Sufism reconsidered," Der Islam, 70 (1973): pp. 64-71; for a response to this criticism, see: John O. Voll, "Neo-Sufism: Reconsidered Again," Canadian Journal of African Studies Vol. 42, No. 2/3 (2008): pp. 322-324. Cornell, Realm of the Saint, p. 219; see also pp. 226-227. Fritz Meier also discussed the history of the term taríqa Muhammadiyya, and traced back its earliest use to the Ottoman scholar Muḥammad b. Pīr 'Ali al-Birkawī (d. 981/1573); cf. Nachgelassene Schriften, pp. 335-346, where he also discusses the further history of the term after al-Birkawì. Ibid. p. 157 . 
the entirety of the traditionalist path towards God. ${ }^{13} \mathrm{He}$ mentions it in his earlier-quoted letter to the Sufi shaykh al-Manbiji, referring to the tariqa Muhammadiyya as the sound religious path that maintains a perfect equilibrium between the law and the spiritual. ${ }^{14}$ Its second mention is in a treatise that addresses al-Ghazâli's claim that the Sufis are the best of all Muslim groups he had studied (the 'groups' being the mutakallimūn, the Ismāiliyya Shi'ites, the philosophers, and the Sufis). Ibn Taymiyya's response is that "he [alGhazāili] was not aware of the path of the Ahl al-Sunna wa-al-Hadith from among the knowers [of God] ('ärifin) and thus makes no mention of it, even though this is the pure Muhammadan way (al-taríga al-muhammadiyya almahḍa)..."15 What is interesting here is that, like al-Wāsițī, Ibn Taymiyya equates the Muhammadan way with the path of the Ahl al-Hadith.

This raises the question as to whether it could have been al-Wāsițī who had first coined the term, or whether he took it from his master. ${ }^{16}$ Initially, I had deemed the latter option more plausible, since it was, after all, the Hanbali shaykh al-Islām who guided al-Wāsițī to focus on the Prophet's biography.

13 For Fritz Meier's mention of Ibn Taymiyya in this regard, see Fritz Meier's Nachgelassene Schriften. Band 1. Bemerkungen zur Mohammedverehrung. Teil 2. Die täșliya in Sufischen Zusammenhängen. Herausgegeben von Bernd Radtke (Leiden: Brill, 2005), pp. 333-334. Ibn Taymiyya, $M F$, vol. 2, p. 452 .

15 Ibid. p. 57.

16 It is necessary to mention that Éric Geoffroy (in "Le traité de soufisme," p. 93) discusses several of the particularities of al-Wāsițī's concept of the Muhammadan way, among which the method of connecting to the Prophet's incorporeal presence, which we will elaborate on below. In this method Geoffroy recognizes what he calls an "Akbarian heritage." He argues that it was due to al-Wāsițî's choice to settle in Damascus that he practiced caution in the formulation of his teachings, which would have been why he only referred to certain doctrines "in an allusive way without naming them." Thus, Geoffroy, continues, "he does not literally use the expression nūr muhammadī or haquiqa muhammadiyya, for this would be equivalent to validating the Akbarian doctrine of 'the perfect man' (al-insān al-kāmil), reproved by Ibn Taymiyya." It is certainly not impossible that our Iraqi Sufi was in some way influenced by Ibn 'Arabī's school in his formulation of the Muhammadan way, since he was familiar with its teachings as we have seen in the previous chapter. However, his elaboration on the concept is so different from what Ibn 'Arabī's doctrine says regarding the Muhammadan reality (al-ḥaqiqa al-Muhammadiyya) that this seems farfetched to me; cf. for instance: Addas, Quest for the Red Sulphur, p. 7677; Michel Chodkiewicz, "Towards Reading the Futûhât Makkiyya," in The Meccan Revelations Volume II, ed. Michel Chodkiewicz (New York: Pir Press, 2004), pp. 30-34. Moreover, we may note that the concept of the Muhammadan light (al-nūr alMuhammadī) can actually be traced back to the ninth century already, cf. Vincent J. Cornell, Realm of the Saint: Power and Authority in Moroccan Sufism (Austin: University of Texas Press, 1998), p. 218. So, at first sight, I would argue that there is no explicit indication that the Muhammadan way contains purely Akbarian influences. 
However, as the following study of al-Wāsițìs writings will show, there are indications that it may in fact have been the other way around.

In order to understand the roots of the tariq a Muhammadiyya we must return to the moment al-Wāsiți had started following the Damascene traditionalists, right before he renounced the Shādhiliyya. We may recall that he closed his autobiography with the conclusion that the best path towards God is to combine the theological foundations of the traditionalists with the Sufism of the Shādhiliyya. His story appears to continue in Qã'ida fı̀ așnāa al-ta'alluh wakhușussịyyat ta'alluh kull țāiifa min al-țawäì (Precept on the Ways to Exercise Devotion to God and Every Group's Particularity in [Their] Exercise of Devotion), a treatise that clearly postdates his autobiography. Here he mentions that he increasingly noticed that the tastes $(a d h w \bar{a} q)$ of the Sufis he had accompanied were at odds with the essentials of the traditionalists he now aspired to follow. He observed, for instance, that the latter group's affirmation of God's highness and aboveness over His Throne (al-uluw wa-al-fawqiyya 'alä $a l$-'arsh) has an illuminating effect on the heart, so that their taste (dhawq) conforms to the verses of the Qur'an, exactly as revealed to the Prophet. But when occupied with his spiritual state during the tastes of the Sufis, al-Wāsitị says that his heart would experience constraint $(d \bar{l} q)$ during the recitation of the Qur'an. While he had initially thought that this was simply due to the triumph of this spiritual state, he gradually became convinced that this only occurred when he turned away from the Prophet's rühāniyya - his spiritual presence - in favor of the rūhanniyya of certain Sufi shaykhs. ${ }^{17}$ It was only among the traditionalists that he was able to connect to the Prophet's rühāniyya. Thus, he claims his heart became illuminated by the lights of prophethood, the hadith, and the sir a, all subjects he was now closely studying under the guidance of his newly found shaykhs. Nonetheless, he could not help feeling that the traditionalist path was incomplete without the intensity he experienced in the nearness (qurb) and intimacy (uns) that he found through the rūhāniyya of the Sufis he so greatly admired. ${ }^{18}$ Referring to himself in the third person, he reflects upon this episode as follows:

17 We have come across the term rūhäniyya several times now. Due to its significance to the subject at hand, it is in place to provide a brief explanation of it here. Al-Wāsiți clearly expected his reader to know what it is he is speaking of, as he never explains what he exactly means by the term. Éric Geoffroy translates it as "présence spirituelle," and explains that it often means something's spirituality as opposed to its corporeality. When it comes to the rūhanniyya of a deceased Prophet or saint, he says, it refers to their spiritual impulse, or even his subtle body, cf. "Le traité de soufisme," pp. 89-9o. In light of alWāsiți’s use of the term, I agree with Geoffroy that this is indeed the term's signification in his works.

18 Al-Wāsiți, Qā'ida fíașnā al-ta’alluh, pp. 151-152. 
O dear God! Would that he knew that it is an incorrect view to hold that the Muhammadan taste (al-dhawq al-Muhammadī) is lacking until it is completed by this other taste [of the Sufi shaykhs]! On the contrary, the Muhammadan taste is perfect and complete and, hence, all good that these [other] paths contain only branches from it, despite their deviation from it. All good that they contain comes from the Muhammadan taste, while any gloom and darkness that they have comes from their deviation from it. Thus this man fell into a state of confusion, which only God knew, and so he sought His help and appealed to Him to guide him. ${ }^{19}$

In short, as the contradictions between the way of the Sufis and that of the traditionalists became clear to him, he could not but turn to God for guidance.

And guidance he received, so he tells us. God facilitated the withdrawal of all other tastes from the core of his heart (sirr), he writes, enabling him to focus completely on the rühanniyya of the Prophet without interference from the rühāniyya of any shaykh or Sufi master. In doing so he was provided with the definite way out of his state of confusion, which he shares with his readers in the following anecdote, again written in the third person:

When he did this, God disclosed an idea to his insight (bașira) that alludes to a sublime point, of great significance to those who recognize its worth. It was an inspiration (ilhām ${ }^{a n}$ ) that came from God's grace upon this weak and confused servant, whose state of affairs had brought him into a depression. This [inspiration] was that it is this rūhanniyya of the Messenger (Ș) that is linked [directly] to the Lord ('AJ), in the sense that it is His law and His path, and the very Book that He revealed, and His spirit $\left(r \bar{u} h\right.$ ) which He bestowed upon His servant and Messenger. ${ }^{20}$ It is this [rühāniyya ] that He loves and is pleased with, and it is this [rühāniyya ] that contains no deviation between it and Him. On the contrary, it corresponds with Him in every respect! When this point became firmly established in his innermost secret (sirr), and his heart drank from it in certainty of it, and his soul became convinced of its correctness - then the Abrahamic-Muhammadan state of intimate friendship made it clear

$19 \quad$ Ibid. p. 152.

20 A reference to the Qur'an, where we often find that there is a particular rūh that would serve as a vessel of the revelations God sent to the Prophets. With regard to the Prophet Muhammad's contact with this rüh, see for instance Q. 26:192-194: "Truly it is the revelation of the Lord of all Being, brought down by the Faithful Spirit (al-rūh al-aminn) upon your heart [Muhammad], so you would be one of the warners." 
to him that, in many respects, what he used to find during the Sufi taste was [actually] the opposite of what he thought it was! ${ }^{21}$

This is perhaps one of the most significant passages on our current topic in alWāsițî's writings, because it presents us with the first-hand account of the way in which the tariqa Muhammadiyya was conceived. We will therefore briefly recount what it is that we are being told here.

The first matter of import is that while his step towards the establishment of the taríqa Muhammadiyya was certainly deeply influenced and, in a sense, even provoked by Ibn Taymiyya (and perhaps also other members of the Taymiyyan circle), it was in the end al-Wāsiți himself who gave it form. The above anecdote gives the impression that what we are dealing with here is a key aspect of his method in sulük that was very much his own conception.

The realization al-Wāsiți claims to have reached through divine intervention was that the purest link between man and God is not found through any Sufi shaykh, but only through the incorporeal presence of the Prophet, his rühāniyya, as his corporeal being has passed away from the material world. But since the Prophet was the vessel of God's speech on earth and, as such, the embodiment of the Qur'an, his spiritual presence continues to be mankind's guide to God.2 ${ }^{22}$

Another point of interest is found in the last sentence of our quote, where al-Wāsiți makes mention of the Abrahamic-Muhammadan state of intimate friendship, 'al-hāal al-Ibrāhìmì al-khalìlı̀ al-Muhammadì', which later in the same treatise he calls the only correct spiritual state. ${ }^{23}$ We must take note that he is by no means implying that the tariqa Muhammadiyya is mixed with the ways of other Prophets, such as that of Abraham in this case. It is to him wholly Muhammadan. However, for our Iraqi Sufi the bond between these two Messengers, Abraham and Muhammad, is particularly significant in that God took both of them as His khalīl, or intimate friend (hence the added adjective "alkhalïlı" in the quoted passage) ${ }^{24}$ While this state of intimate friendship with God (khulla or khilla) was particular to their status as Prophets, al-Wāsiți holds that the wali, or 'friend of God,' can also attain a share of it, which he refers to

21 Al-Wāsițī, Qā'ida fì așnāf al-ta'alluh, p. 153. The last sentence reads: "akasa 'alayhi al-ḥàl

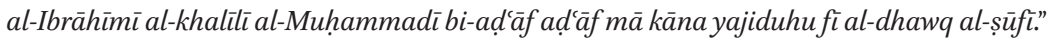

22 Ibid.

23 Ibid. pp. 153-154.

24 In his Qā'ida tatimma li-hādhihi al-qā'ida fì al-ta’alluhāt, p. 156 al-Wāsițī specifically addresses this issue, and cites a canonical hadìth in which Muhammad reportedly said that, like Abraham, "your companion," that is, Muhammad, "is the intimate friend of God." For this tradition, see for instance: Muslim, al-Musnad al-ṣaḥịh, vol. 4, p. 1855. 
elsewhere as the station of Abrahamic-Muhammadan friendship (maqām alkhulla al-Ibrähimiyya al-Muhammadiyya). ${ }^{25}$ As we shall see in chapter 5 , the final stage in al-Wāsițī's Sufism is precisely the point at which God takes the sălik as His beloved (mahbūb), which we may take as an indication that he viewed the terms khalïl and mahbüb as synonyms in that regard. If we return, then, to our passage from Q $\bar{a}$ ida fi aṣnăf al-tảalluh, we may conclude that it was the above divine inspiration he claims to have experienced that compelled him to connect the entirety of his spiritual journey, from its beginning to its highest peak, to the example of the Prophet Muhammad.

What we learn from this is that, as suggested in the beginning of this section, al-Wāsiți aimed to distinguish his sulūk from that of other Sufis. By laying claim to the Prophet as the main source for spiritual guidance he effectively granted Prophetic authority to his teachings, which now represented the authentic inward Sunna rather than the conceptions of some Sufi master. We may understand this in light of his effort to formulate a Sufism that is compatible with the puritan, nușuss-based principles of the Ahl al-Hadith. With this background in mind we now turn to his other writings to study how exactly the Prophet should function as a guide on the Muhammadan way.

\subsection{How to Practice the Muhammadan Way}

One of the first steps in the Muhammadan way that is repeatedly mentioned throughout al-Wāsițīs works is that the sālik should take the Prophet as his shaykh and stick to his guidance, inwardly and outwardly. ${ }^{26}$ The proof for that, he says, is found in the Qur'an, where God commands the Prophet to say to his followers: "If you love God, follow me, and God will love you and forgive you your sins" [Q. 3:31].72 Several times al-Wāsiți compares this relationship with the Prophet to the loyal devotion that the Sufis display towards their shaykhs, concerning which he says: "stick to him like the fuqarä' in our age stick to their shaykhs." 28 Beneath the surface of this remark, and others like it, clearly lays his frustration with the way he had often witnessed the Sufis he met during his travels putting far too much emphasis on their shaykhs. By allowing their hearts to be filled with the secrets $(a s r \bar{a} r)$ and authority (rabbāniyya) of their shaykhs, he argues, they have become veiled from the guidance

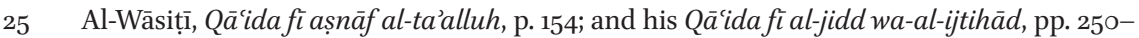
251.

26 See al-Wāsițī's 'Umdat al-țullāb, p. 198; Qā'ida mukhtașara, p. 25; Miftāh țarīq al-muhibbīn, p. 279; Wașiyya ilā ba'd al-quḍāt, p. 141.

27 Al-Wāsițī, Qã̄idat al-rūhāniyyāt wa fìhā bayān li-mā qabluhā, p. 297.

28 Al-Wāsițī, Wașiyya ilā ba'̣̂l al-quḍāt, p. 141; For similar statements, see his: Qā'ida mukhtașara, p. 25; Miftāh al-márifa wa-al-ibāda, p. 264; al-Bulgha, f. 7ob-71a.
} 
and supervision of the Messenger, and thus deviate from the path of arrival $(w u s ̦ u \bar{l})$. He believes that the true reason why the Sufis fail in that regard is because they are unable to extract the secrets of spiritual knowledge (asrār alma'rifa) from the Sunna themselves, thinking that their shaykhs have already done this for them: "They thus allow the Sunna to take direction over their outward being, while turning towards their shaykhs when it comes to the divine secrets and realities (al-asrār wa-al-haqāìq)." ${ }^{29}$ But as he explains in a metaphor, the Prophet is like the pure beginning of a spring; if you fail to drink Muhammadan fagr directly from him, you will be taking water that has been mixed with salty earth, whose colors have turned yellow due to its distance from the source. ${ }^{30}$

The main drive behind attaching oneself to the Prophet ought to be love, which he divides into two categories. The first of these is an obligatory (fard) expression of love, the second a commendable (sunna) one. Obligatory love is to accept what the Prophet has brought in the way of worship for the sake of God's love, to abide by the commands and prohibitions as revealed to him by God, and to strive for the victory of God's religion in jihād with one's life and wealth. ${ }^{31}$ To perfect the former, the sālik has to practice the second category of love for the Prophet, which is to closely follow him. This is realized in two ways.

First, one is to excel in imitating his example and to constantly remember him and hold him in great awe, to the degree that the heart trembles at his mention. He explains that one of the methods to reach this is to incorporate praise for the Prophet in one's daily litany (wird). Litanies were employed by practically all Sufi groups of his age, and mostly consisted of a specific set of Qur'anic verses and invocations put together by a shaykh for the purpose of recital at fixed times. While it is not mentioned whether al-Wāsiți himself ever composed one for his disciples, we know from his writings that he strongly encouraged them to take a litany to recite during the last third of the night, and that this should include a multitude of prayers for blessings upon the Prophet (kathrat al-șalät 'alayhi), commonly known as the tașliya. ${ }^{32}$

29 Al-Wāsițī, 'Umdat al-țullāb, pp. 198-199.

$30 \quad$ Al-Wāsițī, Qā'ida mukhtașara, p. 24.

31 Al-Wāsiți, al-Sirr al-mașūn, p. 46, and this is mentioned as the third necessary aspect of love for the Prophet in Qawā'id al-nubuwwāt, p. 3oo. It must be noted that the necessity of adhering to God's commands and avoiding His prohibitions is a catchphrase repeated endlessly by al-Wāsițī throughout his writings.

Remembering the Prophet's attributes and closely following him is the second necessary aspect of love for the Prophet in al-Wāsițìs Qawā'id al-nubuwwāt, p. 3oo. For his mention of the tașliyya in the wird, see: al-Sirr al-mașūn, p. 46 where he names it as an aspect of

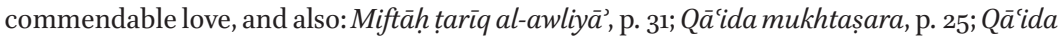


A second way to realize commendable love for the Prophet is to acquire intimate knowledge (márifa) of him. ${ }^{33}$ What is interesting here is that al-Wāsiți does not appear to define the term ma'rifa as some purely spiritual, God-inspired form of knowledge, as is its usual connotation in Sufism. He holds that there are degrees to ma'rifa, with ma'rifa of the Prophet being the first essential foundation. ${ }^{34}$ As he explains it, this particular form of knowledge is the accumulation of as much detailed information about the Prophet's biography and Sunna as one can acquire, leading to a profound and, indeed, spiritual insight into his being. This is only achieved by reconstructing all facets of his life, from its beginning to its end, through a study of the nușuṣs. Of particular importance is the genre of Prophetic biography (sing. sirra, pl. siyar) and its subcategories, such as the accounts of his military expeditions (maghāzi ) and the aforementioned proofs of Prophethood (daläil al-nubuwwa), wherein special focus is laid on the Prophet's character and the stories of his miracles and predictions. A crucial role is also allotted to a study of the hadith collections: first and foremost the Sahịh books, followed by the Sunan and Musnad categories to acquire more detail. ${ }^{35}$

In al-Wāsițīs view, any reasonable person who devotes himself to márifa of Muhammad's Prophethood with an unbiased, rational approach should become convinced that he was indeed God's Messenger. He argues that since his Prophethood is the pillar of sound faith upon which the religion is built, it is essential for the sālik's heart to reach certainty about him and that all doubts are cast away. ${ }^{36}$ The importance of this ma'rifa to the early stages of sulük is undoubtedly also what motivated our Iraqi Sufi to himself compose several books on the Prophet's life. ${ }^{37}$

fí bayān 'amal yawm wa-layla li-al-abrār wa-'amal yawm wa-layla li-al-sāirī̄n ilā țarīq almuqarrabin jaialnā Allāh minhum, p. 70. On the practice of taking a wird, see also: Madkhal ahl al-figh, p. 83. On the use of the tașliya in the litanies of the Sufis, see: Meier, Nachgelassene Schriften, pp. 290-302.

Al-Wāsițī, al-Sirr al-mașūn, p. 46. Gaining ma'rifa of the Prophet's time and biography and studying his miracles and distinguished status is mentioned as the first necessary aspect of love for the Prophet in Qawāid al-nubuwwāt, p. 299.

34 Al-Wāsițī, Miftāh al-márifa wa-al-'ibāda, p. 265; 'Umdat al-țulläb, p. 206.

35 Al-Wāsițī, Wașiyya ilā ba'ḍ al-quḍāt, p. 141; and also: Madkhal ahl al-figh wa-al-lisān, pp. 49-50; and Qã̄ida fì taqwiyat al-sālik 'alā al-wușūl ilā mațlūbihi, p. 121.

36 Al-Wāsițī, Talqūh al-asrār, pp. 54-55; Qā'ida fì nafȳ̄ al-khawāṭir, p. 241; Qã̄ida fì bayān alțarìq ilā Allāh tacălā min al-bidāya ilā al-nihāya, p. 181; Qã̄ida fì al-umūr al-muwașșila waal-umūr al-qātitia, pp. 216-217. 
With the above ma'rifa acquired, al-Wāsiți takes a fascinating turn when it comes to its further application. There are several instances where he states that the sālik's knowledge of the Prophet's life and times enables him to meet with him:

If, my brother, you yearn for something of these realities of faith (alhaquāiq al-ìmāniyya) and tastes of spiritual knowledge (al-adhwāq alirfanniyya), then think of yourself as if you are in the time of ignorance ( fa-j'al nafsaka ka-annaka fi zaman al-jāhilizya) and travel to the Messenger of God (S) so that you can meet him. Then believe in him and become Muslim at the hands of him. Your journey to him and meeting with him is [done through] your study of his biography (sira) and all that has been narrated from him about his life and normative practice (sunna), and the biographies of his Companions and the elite of his followers. ${ }^{38}$

In similar statements made in other treatises we find al-Wāsiți explaining that ma'rifa of the Prophet enables you to "imagine him in Medina as if seeing him,"39 that "you ought to be present [with him] as if you are seeing him,"40 and that, consequently, "the Prophetic days become such that it is as if they are perceived with the eye."11 In what is arguably his most detailed account on the way to see the Prophet by means of one's acquired knowledge of him, we find that this actually pertains to meeting him and establishing a șuhba relationship with him in a literal sense:

Whoever seeks the greatest bliss, the perfect annihilation $\left(f a n \bar{a}^{3}\right)$ in this world and the Afterlife ... and the unseen treasure ... he must meet the Messenger of God (S) and accompany him. This is achieved by means of those lights [the servant] has within himself that hold fast to his Sunna

..." Other treatises about the Prophet are Qã ida min daläil al-nubuwwa, pp. 302-309, and his Hayāt al-qulüb, pp. 74-88, which both deal with the proofs of his Prophethood in particular.

38 Al-Wāsițī, Lawāmi al-istirshād fi al-farq bayna al-tawhìd wa-al-ittihāad, p. 94. For the translation, I cite my article: Arjan Post, "A Taymiyyan Sufi's Refutation of the Akbarian School: 'Imād al-Dīn Aḥmad al-Wāsițī's (d. 711/1311) Lawāmic l-istirshād," in CHESFAME proceedings $I X$, ed. K. D’Hulster, G. Schallenbergh, \& J. van Steenbergen (Leuven, Paris, Bristol: Peeters, 2019), p. 322.

"Yatașawwarahu fìl-Madīna... ka-annahu yarāhu," cf. al-Wāsițī, Qã̄ida fì taqwiyat al-sālik 'alà al-wușūl ilā mațlūbihi, p. 121.

40 “Wa-anta hạạdir ${ }^{u n}$ ka-annaka tarāhu," cf. al-Wāsițī, Miftāh țarīq al-awliyā’, p. 31.

41 "Wa-tașìru al-ayyām al-nabawiyya ka-annahā bi-manżir al-'ayn," cf. al-Wāsițī, Qāंida fì alumūr allatìyanbaghī an takūn hamm al-sālik, p. 193. 
and the external aspects of his law (sharîatihi). These lights are produced amidst the sparks of [the servant's] endurance in adhering to the narrated traditions (al-ittib $\bar{a}^{c}$ li-al-äthār), manifestly with his outward body parts, and inwardly with his intentions. Now, meeting [the Prophet], visiting him, and witnessing him is not conceived with one's external sensory perception (al-hiss al-zähir), for he has passed on from the world of manifestation to the world of the unseen. Accompanying him and witnessing him can only occur while being absent in the unseen realm (ghayb ${ }^{a n}$ fighayb), and inwardly in one's innermost secret (sirran fi sirr).

When the servant knows [the Prophet's] biography, his times, his Sunna, his distinguishing marks, his supernatural abilities (khawäriqahu), his miracles (mu jizātahu), his signs, and his marks of honor, and knows the relationship between him and the Prophets who preceded him - he has then come to know him, arrived unto him with his heart, and witnessed him in the unseen (fial-ghayb), provided that he loves him at that point.

An indication of love for him is [the servant's] concern for intimate knowledge (ma'rifa) of [the Prophet's] Sunna after [having acquired] intellectual knowledge ( $\mathrm{ilm}$ ) of his biography. He must then clothe himself with this [love], witnessing the lights of his splendor as if he is with him in his age, neither separating himself from him inwardly nor manifestly! ... As it is said:

Although you are in the unseen, veiled from my gaze

The heart looks at you from a distance, far away. ${ }^{42}$

Whoever at one point during his lifetime is overtaken by this state, he has arrived unto the Messenger (Ṣ) and his șuḥba $!^{133}$

To place the above passage in al-Wāsițīs overall narrative on the Muhammadan way, let us reiterate what we have thus far seen. We began with the path towards love for the Prophet, which requires conforming to the religion that God revealed to him, imitating and remembering him, and acquiring ma'rifa of him through a study of the nușuss. It is then through the combination of all these steps and the love that is thereby realized that the doors to meeting him and accompanying him are opened. This occurs in the unseen realm, al-ghayb, perceived by the human being with his innermost secret, al-sirr, which al-Wāsițī

42 Interestingly, this line comes from a poem by the controversial Sufi al-Ḥusayn b. Manșūr al-Ḥallāj (d. 309/922), see his Dīwān al-Ḥallāj, ed. 'Abduh Wāzin (Beirut: Dār al Jadīd, 1998), p. 8 o.

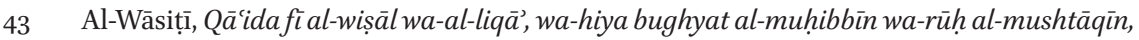
pp. 268-269. 
defines as the heart's kernel (habbat al-qalb) ${ }^{44} \mathrm{He}$ describes this process on different occasions as seeing the Prophet with the eye of one's heart (bi-'ayn qalbihil'aynay fu'ädika) ${ }^{45}$ one's insight (bașīra), ${ }^{46}$ or one's inner vision ('iyān) ${ }^{47}$ all of which he uses as synonyms. In one treatise he calls it 'the witnessing of Prophethood' (mashhad al-nubuwwa), wherein the sālik witnesses the possessor of Prophethood (șâhib al-nubuwwa). ${ }^{48}$

Although he only rarely attempts to elaborate on the nature of this vision, it clearly had to do with connecting to the Prophet's rühanniyya. In one treatise he writes that the above-mentioned trajectory of love is aimed at reaching a state wherein one's spirit becomes intermingled with that of the Prophet (mam$z$ ujat ${ }^{a n}$ bi-al-arwāh $) .{ }^{49}$ In a precept on Prophethood he delves deeper into what he means by that. He explains that when the servant has realized love for the Prophet and clothed himself with it, he obtains the realities of his mysteries from the light of Prophethood; through his bașira he will know the link between Muhammad and the Messengers who preceded him, and acknowledge that their lights come from one and the same niche (mishkāt). He will then find unification (ittiha a d) with his Prophet, and he will be invested with a garment (kiswa) from his clothing. This, al-Wāsițī says, "results in a connection (ittișāl) between their spirits, of which [the servant] will be conscious during his [everyday] conduct (fimu'ämalatihi). ${ }^{.50}$

Based on the above, it becomes clear that al-Wāsiți did not regard the sālik's attachment to the rühanniyya of the Prophet as a mere symbolic act to oppose the Sufis' exaggerated focus on their shaykhs. He conceived it as an actual master-disciple relationship with the Prophet, who in spite of his absence from the material world could still exercise his influence upon the sālik. Since it is the Prophet's rüh, his spirit, that remains accessible in the spiritual world, the connection with him is necessarily one of the spirit as well.

Besides the Prophet himself, we find occasional hints that the elite of his Companions (șahāba) are also allotted a role in the țariqa Muhammadiyya. In al-Wāsițîs view, their guidance is indispensable because they were present as the sira unfolded and God's revelations to their Prophet progressed, and they were, in Qur'anic terms, al-sābiqūn al-awwalūn, the First and Foremost in

Al-Wāsițī, Qāida fì al-umūr al-muwașșila, pp. 221-222.

Al-Wāsițī, Qā'ida fì al-wișāl wa-al-liqä’, p. 269; Qã̄ida mukhtașara, pp. 25-26; 'Umdat alțullāb, pp. 198 \& 206; Qã ida fì taqwiyat al-sālik 'alā al-wușül ilā mațlübihi, p. 121.

46 Al-Wāsițī, al-Tadhkira, p. 29; Qawāìid al-nubuwwāt, p. 300.

47 Al-Wāsițī, al-Tadhkira, p. 29.

48 Al-Wāsițī, Talqūh al-afhām, p. 156.

49 Al-Wāsițī, Q̄ं'ida fì ta'arruf al-nubuwwa ayḍan, p. 313.

50 Al-Wāsițī, Qawā id al-nubuwwāt, p. 300.
} 
following him. ${ }^{51}$ Although he never explicitly says so, he characterizes them as archetype Sufi masters who, due to their proximity to the Prophet, were able to reach utmost perfection in acquiring a set of spiritual qualities that we may recognize as distinct Sufi terms:

They [the elite of the Companions] were the people most immersed in spiritual states, such as renunciation (zuhd), trust (tawakkul), contentment (ridā), love (hubb), longing (shawq), annihilation (fanā), and subsistence $(b a q \bar{a})$. But due to the strength of their faith and the exaltedness of their ranks, the effects of intoxication (sukārā) that these states bring about were not visible on them. On the contrary, they were strengthened by the light of Prophethood so that they applied these states in [their] deeds and strove on the path of God through long, dark nights. This is the utmost degree of perfection! Do not wonder at this as you would at someone who is sober and drunk at the same time, for the divine gift contains an abundance of Muhammadan traits that continued through the elect of the Companions, giving them spiritual strength and stability (al-quwwa wa-al-tamkin), and a state of separation while being united (al-farq fi $a l$-jam ${ }^{\prime}$ ), and of sobriety while being intoxicated (al-șahı fi al-sukr)!52

The last sentence in particular reflects al-Wāsițīs sentiment that the Companions had reached spiritual perfection. What is implied is that even as they were completely absorbed in their awareness of God, they always had their feet firmly planted in the material world. And since the elite of the Companions cannot possibly be surpassed by anyone after them,

it is from what remains of their milk (rid̄a ihim) that those [who come after them] will have to be nurtured, and on them that they have to rely for the spiritual realities (al-haqāiq). For they had a certain drink $\left(\operatorname{shara} b^{u n}\right)$ that they would take, of which there [still] remain drops that will quench the thirst of the people who follow them. ${ }^{53}$

The title al-säbiqūn al-awwalūn comes from the Qur'an, 9:100: "And the Foremost, the first of the Emigrants and the Helpers (al-sābiqūn al-awwalūn min al-muhājirīn wa-al-anșār ) and those who followed them in good-doing." See also: al-Wāsițī, 'Umdat al-țulāab, pp. 207-208.

$5^{2}$ Al-Wāsițī, Lawāmic al-istirshād, pp. 91-92; Post, "A Taymiyyan Sufi's Refutation," p. 319.

53 Al-Wāsițī, Lawāmi` al-istirshād, pp. 94-95. 
As with the Prophet, al-Wāsiți held it possible to enter into their presence and perceive them with the eye of the heart through a study of their biographies. ${ }^{54}$ For although they have passed away, he says, "for those whose hearts are opened to their guidance, they are, in reality, alive with God!"55

\subsection{The Role of the Shaykh in the Muhammadan Way}

Based on the above, the question arises whether al-Wāsiți saw any need for a living shaykh as a spiritual guide for those who follow the Muhammadan way. He often gives the impression that the Prophet suffices as one's shaykh. This, however, is not entirely so. At times he reveals that in the beginning of the path there is in fact a dire need to enter a master-disciple relationship with a teacher who is a knower of God (ustāadhun 'ärifun), because the spiritual novice (murid) may be susceptible to all kinds of excesses under the guise of Sufism. Constant fasting, for instance, may appear as a pious deed that brings about proximity to God, but in the long term it can do more harm than good to his spiritual state, and eventually even cause him to deviate. ${ }^{56}$ It is one of the tasks of a spiritual teacher to guide him through any such pitfalls. In light of its necessity in the Muhammadan way, it is thus necessary to briefly scrutinize how al-Wāsițī envisioned this master-disciple relationship.

First, there was, in his view, only one kind of shaykh who is truly fit for tarbiyat al-sälikin - the spiritual training of the travelers unto God - and that is someone who has successfully traversed the entire path himself. From alWāsițî's perspective, this means that he must have gone through all the steps of sulūk (which will be discussed in the next chapter) and has thereby arrived unto God spiritually. In the terminology of the Sufis he explains that such a person has returned from intoxication $(s u k r)$ to sobriety (șahw), from annihilation $($ fan $\bar{a})$ to subsistence $\left(b a q \bar{a}^{\prime}\right)$, and attained the station of stability (tamkin) - though none of this is on his own accord, for a master of this degree has been chosen by God to become a guide (murshid) for the murid. ${ }^{57} \mathrm{God}$ desires the existence of such men, al-Wāsițī says, to serve as proofs for Him, to cure mankind's spiritual diseases, take charge over them and govern them, and lead

\footnotetext{
54 Al-Wāsițī, 'Umdat al-țullāb, p. 207, and: Lawāmi' al-istirshād, p. 94.

55 Al-Wāsițī, Lawāmi' al-istirshād, p. 95.

56 Al-Wāsițī, Qã̄ida fì al-umūr allatī yanbaghī an takūn hamm al-sālik, p. 191; Qã̃ida fì alumūr al-muwașșila, p. 222; Qāंida fì tajrīd, pp. 254-255; Miftāh țarīq al-muhibbīn, pp. 280281.

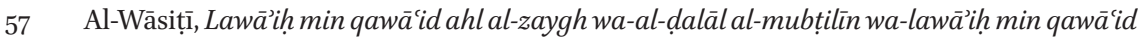
țarīq al-șādiqīn, p. 131; Madkhal ahl al-fiqh, p. 50; Mìzān al-shuyūkh, p. 241.
} 
them unto the path of the revealed law (sharîa), away from falsehood. They are, in short, the successors of God's Messengers (khulafä'al-rusul). ${ }^{58}$

On rare occasions al-Wāsițī reveals that he ideally envisioned Sufism being practiced in a group structure wherein murids are organized around the guidance of such a shaykh. This is attested to most evidently in his treatise on the way of Muhammadan faqr, where he makes mention of specific rules of etiquette for Sufi aspirants to observe, not only towards their shaykh, but also towards one another. Among these etiquettes we find that the murid should accompany his fellow fuqara $\overrightarrow{3}$ with admiration, renown, and reverence, and prefer them over himself. ${ }^{59}$ However, if one of them displays insolence towards their shaykh, by for instance shouting at him with harsh words and mentioning his shortcomings, al-Wāsiṭi maintains rather serious repercussions. His verdict is that such an aspirant

should no longer be accompanied after this, for there is no penance for the disobedience of a murìd among the fuqara $\bar{a}$. That is because that subtlety of the heart (al-latîfa al-qalbiyya) that is pursued by means of his spiritual training (tarbiya), through which a share of the Divine may reach him, has been disrupted [by his actions]. Indeed, this share only reaches the murìd when he reveres his shaykh, respects him, honors him, and loves him! ${ }^{60}$

Our Iraqi Sufi puts so much emphasis on observing due propriety ( $a d a b)$ with one's shaykh because this is, in his view, directly linked to the propriety that is due to God and the Prophet. After all, as we noted above, he considers the true Sufi shaykh a successor of the Messengers, so to revere him is to revere God and the Prophet. For that reason, the aspirant should pay close attention to his shaykh, refrain from disagreeing or arguing with him, and carefully inquire into his spiritual expressions ('ibāa $\bar{a} t)$ and states $(a h w w \bar{a} l)$ with polite words when there is something obscure in them. ${ }^{61}$ In return, the shaykh should teach the aspirant how to be rid of the veils that cover his heart, until the utmost end of his guidance is reached.

Al-Wāsiṭi maintains that spiritual guides are essentially intermediaries (wasä $\vec{i}$ ) between this world and the Prophet. ${ }^{62}$ There thus comes a degree in

$5^{8} \quad$ Al-Wāsițī, Mìzān al-ḥaqq wa-al-ḍallāl, p. 223; this treatise is identical with his Qā'ida fi sifat al-'ubüdiyya, pp. 47-48.

59 Al-Wāsițī, Qāंida mukhtașara, p. 35.

6o Ibid. pp. 34-35.

$61 \quad$ Al-Wāsițī, Madkhal ahl al-figh, pp. 48-5o.

62 Al-Wāsițī, Madkhal ahl al-figh, p. 49; Mīzān al-shuyūkh, p. 241. 
the sălik's journey where he arrives unto the Prophet, and his shaykh's mediating role is no longer required. This occurs when the earlier-mentioned Muhammadan state is acquired, for then

the vision of his own shaykh who brought him to the Prophet (Ș) vanishes before him, and he sees the Prophet (Ș) from the niche (mishkāt) of his own self (nafs) rather than from the niche of his shaykh. In the beginning [of the path], the murid may perceive the Messenger through the $\operatorname{arch}(t \bar{t} \bar{q} q)$ of his shaykh, until the Messenger (Ș) may at times take shape within his innermost secret (sirrihi) through his shaykh's instruction (kayfiyya). When he ascends to this rank, he rises from the intermediaries (wasä $\bar{i}$ t) to the Messenger (Ș), from whom he then receives distinguished love (al-hubb al-khāṣs ), and his spirit will truly be united with his spirit!63

This is a unique passage in that it is perhaps the only instance where al-Wāsiṭi explicitly shares with us how he envisioned the role of the shaykh in the tariqa Muhammadiyya. The shaykh's niche through which he sees the Prophet is likely in reference to the shaykh's spiritual connection with the Prophet. What seems to be intended is that the shaykh thereby provides guidance through all the steps we have gone through, from the beginning of this chapter up to the point where the aspirant, too, becomes connected to the Prophet by his spirit, and subsequently perceives him in the unseen. What the sālik reaches at that point is required for his further advancement towards intimate knowledge of God, which is the topic of the next section.

Up till now we have followed all the basic steps of the Muhammadan way that can be found scattered throughout al-Wāsițīs writings. If we go back to the beginning of the current section, and question once more to what degree we may discern a Taymiyyan influence with all the ground we have now covered, our initial hypothesis that al-Wāsițin himself had developed the concept of the tariqa Muhammadiyya as the way to connect to the Prophet and his Companions becomes all the more plausible. ${ }^{64}$ This does not detract from the fact that Ibn Taymiyya's influence is visible in the role our Iraqi Sufi allots to the study of hadith and the biographical sources on the Prophet and his Companions - after all, it was the Hanbalī shaykh himself who pointed al-Wāsițī in this direction. Herein we may recognize a distinctly traditionalist, nuṣuṣs-based

63 Al-Wāsițī, Qã ida fì al-ḥubb fì Allāh ḥaqūqat ${ }^{a n}$, p. 54.

64 Geoffroy has also noted the originality of al-Wāsițīs take in that regard in: "Le traité de soufisme," p. 88. 
spirituality, an approach that extends even more visibly to the topic we will cover in the next section.

While the effort to harmonize traditionalism with Sufism is thus clearly visible, we may also observe that al-Wāsiți occasionally tilts the balance more towards Sufism in his doctrine. This is especially apparent in the method of connecting to the Prophetic rühanniyya and some of the Sufi terminology he uses to describe this process, but also in the way he envisioned Sufism being practiced in a group structure around the guidance of a complete Sufi master. In view of his position as the teacher of Sufism in the Taymiyyan circle, we may take this as an indication that there was apparently a crowd for such teachings among the traditionalists of Damascus. The same can be said for the masterdisciple structured practice of Sufism: The mere fact that al-Wāsiți deals with the topic seems to imply that such was the nature of the relationship he himself had with his disciples as their shaykh al-sulük. We may rightfully question whether he would have chosen to express himself through such language and statements if this would have met with the disapproval of the traditionalists who sat at his feet. Since we know he was a respected member of the Taymiyyan circle, this tells us that in all likelihood they generally regarded his teachings as quite normative.

If the shaykh is the intermediary between the sālik and the Prophet, then the Prophet is the intermediary between the sālik and God. It is, after all, by means of the Prophet that God has made Himself known to mankind;65 as al-Wāsiți puts it: "Prophethood is a stairway and an ascension unto knowledge and ma'rifa of God by which God is known and served." ${ }^{6}$ We have already noted that, according to al-Wāsițīs conception of the Muhammadan way, intimate knowledge of the Prophet is but the first of the degrees of ma'rifa. It ultimately serves as the required foundation for the branches of ma'rifa of the Divine. In other words, when the sālik has mastered intimate knowledge of the Rasül, the Messenger, he is ready to ascend to intimate knowledge of the Mursil, the Sender, that is, God. This is done first through God's risāla, the message He sent to Muhammad in the form of the Qur'an. In addition, knowledge of God is obtained by studying the Sunna in the form of hadith $6{ }^{67}$ Our Iraqi Sufi thus

65 Al-Wāsițî, Miftāḥ al-ma'rifa wa-al-ibāda, p. 265; 'Umdat al-țullāb, p. 206; Qã̄ida fì sulūk al-tahqūq ilā ghāyat al-mațālib li-al-sā̉ir ilà rabbihi al-dhāhib, p. 199.

66 Al-Wāsițī, Talqụ̄ al-asrār, p. 55 .

67 Al-Wāsițī, Miftāḥ al-márifa wa-al-ibāada, p. 265; Miftạh țarīq al-muhibbìn, p. 28o. 
proceeds from a study of the nuṣuṣs on the Prophet to a study of the nuṣūs on God. The first steps in acquiring ma'rifa of God are thus very similar to what we have already seen regarding the acquisition of Prophetic márifa.

\subsection{What is Marifa of God?}

Again, rather than being described as knowledge that is the product of a spiritual, God-inspired experience, it is the nușuss themselves that contain the concrete details about God that, when accumulated, provide the sālik with ma'rifa of Him. In this approach al-Wāsițī expresses a note of caution for the Sufis that we have come across several times already in the previous chapters: Sufism ought to be a means to an end, not the end itself. While he accepts Sufism as a legitimate Islamic science that serves to extract spiritual knowledge from the Qur'an and the Sunna, he stresses that it should always be restricted by what the holy texts themselves say. Sufis can never claim to get to know God without the facts of scripture:

Whoever makes the science of the Sufis into the direction (qibla) of his heart, he will be accorded a general state ( $h \bar{a} l^{a n}$ mujmalan $)$ that contains no completeness of detail $(\operatorname{tafṣil})$. But whoever makes it his pathway until he thereby draws the spiritual realities (al-haqä'iq) from the Book and the Sunna to which the sciences of the [Sufi] community ('ulüm al-țäifa) allude, he has been granted success and he has been guided unto a straight path. Indeed, the only perfect, comprehensive, straight path, which contains neither distortion nor deviation, is to seek intimate knowledge of God from whence He has made Himself known to us (ma'rifat Alläh min haythu ta'arrafa ilaynā), through His exalted names and majestic, beautiful attributes, which are articulated in the Mighty Book and stipulated by the Messenger (Ṣ) through the [Prophetic] reports $(a k h b \bar{a} r)$ and the [Qur'anic] verses $(\bar{a} y \bar{a} t)$ on the divine attributes. Now, each of these reports leads to one of the sublime secrets of ma'rifa [of God] and one of the eminent qualities of [His] magnificence by which the gates of spiritual knowledge (al-ma'ärif) are opened to the seekers ... ${ }^{68}$

The essential point that is made in this passage is a recurring rule in al-Wāsițīs formulation of Sufism, echoed throughout his writings, namely, that ma'rifa of God begins with knowledge of the way He describes Himself in the revelation He sent down unto His Prophet. This was in fact a classical position in 
traditionalist theology. ${ }^{69}$ In al-Wāsițī's view, every word spoken by the Prophet about God is a piece of the puzzle of knowledge of God, whether from the Qur'an or from his sayings transmitted in the hadith literature. ${ }^{70}$ The entirety of the descriptions found in the nușuss results in a list of names (asmā’) and attributes (șifāt) by which God wants His servants to know Him, for otherwise He would not have revealed them to His Prophet. So, simply put, for al-Wāsiți the first essential means to marifa of God is to know all of His names and attributes as found in the Qur'an and the Sunna.

However, knowledge of them alone is not sufficient, for it must necessarily be followed by a correct understanding of their meanings. In al-Wāsițìs sulūk this is tightly interwoven with traditionalist theology. In the previous chapter I have already made note of the indissoluble bond between spirituality and theology that his writings display. It is therefore imperative that we first identify and elaborate upon the specific theological discussions that are connected to his views on ma'rifa.

Upon studying al-Wāsițīs oeuvre, one will find that in most instances this endeavor takes us to the very beginning of his sequence of sulük, where the sālik is told that a sound creed (șihhat al-itiqa $\bar{a}$ ) is a condition for undertaking his spiritual journey. For our Iraqi Sufi this means nothing other than abiding by the traditionalist creed of the Hanbali school. ${ }^{71}$ In a Sufi poem preserved by al-Dhahabī he writes accordingly:

And constantly remember [God] after [belief in] the creed based on the Sunna, The creed of Ibn Ḥanbal, which cures the deceases [of the heart]. ${ }^{72}$

As we shall see below, theology is, above all, crucial to the way one ought to deal with the so-called mutashäbihāt, the ambiguous descriptions of God found in the holy texts. Al-Wāsiți argues on several occasions that if the sālik's beliefs in their regard are corrupted this will have disastrous consequences, as

69 For the importance of knowing God as He describes Himself in traditionalist theology, see or instance: Hoover, "Hanbalī Theology," p. 633.

$70 \quad$ Al-Wāsițī, Risāla fì ithbāt, p. 45; Lawāmi' al-istirshād, pp. 94 \& 96; 'Umdat al-țullāb, p. 203; Miftāh țarīq al-muhibbìn, p. 280; Madkhal ahl al-fiqh, p. 50; Hayāt al-qulūb, p. 88; Qāंida fí

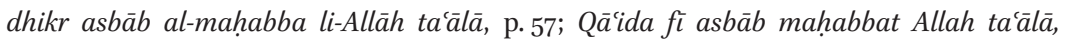
ma'rifatihi, wa-asbāa ma'rifatihi, pp. 61-62; Q̄̄ंida fì taqwiyat al-sālik, p. 122; Qāंida fì bayān al-țarīq ilā Allāh tạầā min al-bidāya ilā al-nihāya, p. 181.

$71 \quad$ This has also been noticed by Geoffroy, "Le traité de soufisme," pp. 85-86.

72 Al-Dhahabī, Mujam al-shuyūkh, vol. 1, p. 3 o. 
the degrees of witnessing God (al-mashähid) he must pursue in the later stages of his journey will necessarily be corrupted as well. ${ }^{73}$

For the roots of the influence of theology on al-Wāsițīs Sufism we again return briefly to his life's story. In the first chapter we have observed that he may have initially followed the Ash'arī school in theology, and at some point became inclined towards traditionalism. And as noted in chapter 3 , at least by the time he fulfilled the task of shaykh in sulük in the Taymiyyan circle, he had clearly reached a degree of proficiency in his newly adopted creed. A closer look at the process of this transition towards traditionalism as described in one of his creedal works reveals that this occurred during a period of confusion and restlessness that plagued him regarding the descriptions of God from the nuṣuṣs whose literal significations are analogous to the attributes of creatures. Does God exist in elevation ( 'uluw) and aboveness (fawqiyya), seated (istiwa $\vec{a}$ ) on His Throne? And should such terms as 'descent' (nuzūl), 'two hands' (yadayn), 'face' (wajh), and others that can be found in the Qur'an and/or hadith in relation to God be considered as actual attributes (șifât) of Him according to their apparent meanings or not?

The way al-Wāsiți saw it, the theological schools he had studied offered four approaches to these issues: The first is to dismiss their concrete realities by applying $t a^{\prime}$ will, a metaphorical interpretation, which was probably the method observed by many of his former Shāfi'î-Ash'arī teachers, and as it seems initially by himself as well. ${ }^{74}$ The second option is to read over them without comment (imrär), which was a position that existed among certain traditionalists. ${ }^{75}$ The third option is to refrain from passing any judgment about them (wuqūf), a position that existed among certain Ash'arīs as we have seen in chapter 2 . While this approach seems very similar to the preceding one, alWāsițī never elaborates on the actual difference between them as he understood them. The fourth option is ithbät, the position he will have found in Ibn Taymiyya's circle, and which he understands as the affirmation of the attributes with their apparent meanings. ${ }^{76}$ After a careful study of the arguments

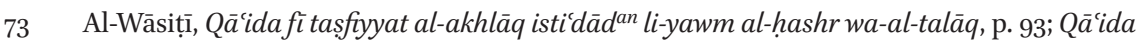
fì bayān al-țarīq ilā Allāh táālā min al-bidāya ilā al-nihāya, p. 182; Qã̄ida fì al-umūr allatī yanbaghī an takūn hamm al-sālik, p. 192; Qã̄ida fì al-umūr al-muwașșila wa-al-umūr alqātíia, p. 217; Qã̄ida fì nafȳ̄ al-khawāttir, p. 241; Wașiyya, p. 137; 'Umdat al-țullāb, p. 202; Miftāh țarīq al-muhibbīn, p. 279; al-Sirr al-mașūn, p. 55; Madkhal ahl al-fiqh, pp. 51 \& 53 .

74 For his initial inclination towards ta'wül, see: al-Wāsițī, Risāla fì ithbāt, p. 26.

75 Imrār was for instance advocated by Ibn Qudāma al-Maqdisī, cf. Hoover, "Hanbalī Theology," p. 633 .

76 Al-Wāsițī, Risāla fì ithbāt, pp. 25-26. It must be noted that although Ibn Taymiyya viewed his theology as being grounded in the tradition of the Ahl al-Hadith, it was quite complex and innovative; on this, see: Hoover, "Hanbalī Theology," pp. 637-638. A good example of 
put forth by the different schools, al-Wāsiți claims to have received an unveiling (kashf) from God that opened his heart to ithbāt and made him turn away from $t a^{\prime} w \bar{l}$ - a claim we may take as indication that he did indeed at one time adhere to the latter position. ${ }^{77}$ This switch would, in effect, have been a turn from the kalam theology of the Ash'aris to the traditionalist theology adhered to by Ibn Taymiyya and his circle.

\subsection{Affirmation versus Metaphorical Interpretation}

This conversion should not be taken lightly, as adherents of both positions had been diametrically opposed to one another for several centuries. In the new traditionalist capital of Damascus, too, dissension (fitna) between Hanbalīs and Ash'arīs (especially the Shāfi'is) was frequently noticeable, both before and after al-Wāsițī settled there. ${ }^{78}$ The Ash'arīs' main criticism towards traditionalists who affirmed the apparent meanings of the above descriptions from the nușus as attributes of God was that this inevitably leads to understanding them in an anthropomorphic sense (tashbih $)$ and likening God to His creation (tamthill). This, they held, contradicts reason and revelation, which both demonstrate that God is utterly transcendent (munazzah) and nothing like His creation. More or less in line with al-Wāsițīs overview discussed above, the Asharīs were roughly divided into two camps when it came to the preferred solution to the problem of the divine attributes. Some preferred to simply delegate the true meanings of such ambiguities from the holy texts to God (tafwied), while another group would resort to $t a^{3} w \bar{l} .^{79}$ Although our Iraqi Sufi disap-

Ibn Taymiyya's argumentation for ithbāt as the affirmation of the apparent meanings of the attributes, and against the use of $t a^{\prime} w \bar{l} l$ - most notably that of the Ash'arīs - is his alFatwa al-Hamawiyya al-kubrä, $M F$, vol. 5, pp. $5^{-120}$. In some respect the approach to the divine attributes appears similar to that of al-Wāsitị, which we will set forth in the following pages of our study.

77 Al-Wāsițī, Risāla fì ithbāt, pp. 40 \& 43.

78 On their fitna in Damascus, see especially: Michael Chamberlain, Knowledge and Social Practice in Medieval Damascus, 1190-1350 (Cambridge: Cambridge University Press, 1994), pp. 169-173.

79 I am indebted to Jon Hoover for sending me his forthcoming article: "Early Mamlūk Ash'arīs against Ibn Taymiyya: on the nonliteral reinterpretation ( $\left.t a^{\prime} w \bar{l} l\right)$ of God's attributes," to be published in: Philosophical Theology in Islam: The Later Ash'arite Tradition, ed. Jan Thiele and Ayman Shihadeh (Leiden: Brill). This article gives a useful and concise overview of the different approaches to the divine attributes among the early Mamluk Ash'arīs. Hoover notes that some of those who resorted to ta'wïl considered this method to be for trained scholars only, whereas others felt this should be the general method for all Muslims. We may also note that safeguarding God's tanzìh has always been at the center of Ash'arism, see: Richard M. Frank, "Elements in the Development of the Teaching of al-Ash'arī” Le Muséon 104 (1991), pp.163-164. For the textual proof for God's utter 
proved of both options, his objection to those who practiced ta'wil was much stronger. Let us therefore briefly consider the line of argumentation of the latter group of Ash'arīs before we turn to al-Wāsițīs own discussions on the matter.

According to the Ash'arīs who made $t a^{\prime}$ wìl, logic dictates that if God exists in an upward direction, seated on His Throne, He is necessarily confined and limited by space. Whenever such is the apparent meaning of statements from the holy texts, they believed that this requires a metaphorical interpretation so as to avoid the attribution of limitation to God. Hence, they interpreted God's sitting on the Throne as His subjugation ( $q a h r$ ) of the Throne. ${ }^{80}$ The same principle applies to corporeal terms in the Qur'an, as found, for instance, in the verse "What prevented you prostrating to what I created with My own two hands (bi-yadayya)?" [Q. 38:75]. They argued that if the term '(two) hands' is taken literally, this means by reason that God has a body and a form. Again, because this is in contradiction with God's utter transcendence, they interpreted the 'hands' as God's creative power (qudra). ${ }^{81}$ It must be noted that al-Wāsițī was not unaware of this line of reasoning. He reveals in several works that he knew very well how such Ash'aris interpret terms from the revelation that they viewed as ambiguous. ${ }^{82}$

However, from his understanding as a traditionalist, there was an intrinsic fallacy to $t a^{\prime}$ wìl in such cases. His argumentation is as follows: Whenever the Prophet intended a certain word or phrase from the revelation as a metaphor, this is either clear through the linguistic context of the wording, or because he explicitly added a statement indicating that a change of the apparent meaning to a metaphorical one is required. ${ }^{83}$ If the Prophet made no indication of $t a^{3} w \bar{l} l$

transcendence, reference is often made to the Qur'anic verse "There is nothing like unto Him" [Q. 42:11]. The diversity of opinions among Ash'arī scholars regarding the divine attributes has since long been noted; see for instance: Allard, Le problème, p. 427.

8o See for instance the well-known Ash'arī authority, 'Abd al-Malik b. 'Abd Allāh al-Juwaynī (d. 478/1085), who is an excellent example of someone who rigorously applies ta'wïl in his Kitāb al-Irshād ilā qawāți al-adilla fì ușūl al-ítiqād, ed. Muḥammad Yūsuf Mūsā \& 'Alī 'Abd al-Mun'im al-Ḥamīd (Cairo: Jamā'at al-Azhar li-al-nashr wa-al-ta'liff, 1950), see on God's aboveness, pp. 39-40, and on His sitting on the Throne, pp. 40-41.

$81 \quad$ Ibid. p. 156.

82 Al-Wāsițī, Risālatuhu ilā al-shaykh al-Maghribī, pp. 105-106; Wașiyya, p. 139; Talqūh alafhām, p. 154; Risāla fì ithbāt, pp. 26.

83 This approach suggests two methods of Qur'anic exegesis: tafsir of the Qur'an through the Qur'an, and 'tafsìr bi-al-ma'thür,' i.e. exegesis on the basis of the Sunna. This hermeneutical approach was also applied by Ibn Taymiyya, see for instance: Walid Saleh, "Ibn Taymiyyah and the Rise of Radical Hermeneutics: An Analysis of "An Introduction to the Foundation of Quranic Exegesis"," in Ibn Taymiyyah and His Times, ed. Shahab Ahmed and Yossef Rapport (Lahore: Oxford University Press, 2010), pp. 144-145. 
by means of either of these two ways, then that is enough to know that the apparent meaning is intended. After all, during the Prophet's teaching sessions both intellectually gifted and deficient individuals would be present, so he will surely have guarded them against any form of misunderstanding when it comes to the revelation. ${ }^{84}$ As an example, al-Wāsiți takes the following words from the Qur'an: "Are you not aware that God knows all that is in the heavens and all that is on earth? Never can there be a secret confabulation between three persons without His being the fourth of them ..." [Q. 58:7]. Here, he says, it is clear that God is not with mankind with His essence, since the context of the verse indicates that it is rather God's knowledge that is with them. In other words, al-Wāsițīs ta'wīl of this particular verse is that they cannot hide from God's knowledge, for He is ever aware of what they do. For an example where ta'will is not allowed, he refers to the earlier example of the Qur'anic words "My (two) hands" (yadayya). While we have noted that a branch of Ash'arīs would interpret 'hands' as God's creative power (qudra), al-Wāsiți contests that there is no indication that a metaphor is intended, because in the Arabic language the word 'hand' that bears the meaning of qudra does not come in pairs. In order for it to be taken metaphorically, it would had to have read the singular form yadī, 'my hand,' instead of the dual form yadayya, he says. ${ }^{85}$ The conclusion is, then, that the attribute of 'hands' is not ambiguous, because it is clear that there is no explicit or implicit proof to view it as such. As a consequence, to make $t a^{\text {'wi }} \bar{l}$ of it would be to strip it of its apparent meaning and subsequently deny it as an attribute by which God describes Himself in the revelation. Besides straying from the method of the Prophet, one would thereby deprive oneself of a piece of the puzzle of ma'rifa and fall short in knowledge of God.

As for the argument of the Ash'aris that affirming such attributes according to their apparent meanings necessarily results in anthropomorphism, al-Wāsiṭ̂̄ replies that this is only from the viewpoint of their inconsistent line of reasoning. Like Ibn Taymiyya, he holds that ithbät is in fact the golden mean between ta'țil, denying God by stripping Him of His attributes, and tashbih, anthropomorphism by assimilating God's attributes to those of creatures. ${ }^{86}$ To underline that He is definitely exempted of the latter, al-Wāsițī frequently states that all of God's attributes ought to be affirmed in a way that befits His majesty and

84 Al-Wāsițī, Risālatuhu ilā al-shaykh al-Maghribī, p. 105; Risāla fì ithbāt, pp. 36; Wașiyya, pp. 138-139; 'Umdat al-țullāb, p. 203.

85 Al-Wāsițī, Risālatuhu ilā al-shaykh, pp. 105-106.

86 Al-Wāsițī, Wașiyya, p. 137. On Ibn Taymiyya's utilization of the middle way, al-wasat, as an argument, see: Jon Hoover, Ibn Taymiyya's Theodicy of Perpetual Optimism (Leiden: Brill, 2007), p. 173. 
magnificence, without imagining them to be in any way similar to those of His creation (bi-la tamthïl) or in an anthropomorphic sense (bi-lä tashbïh), and without inquiring into their modality $(b i-l \bar{a} t a k y \bar{c}) .{ }^{87}$ Like the Ash'arīs, he considers the basis for God's dissimilarity from His creation to be the Qur'anic verse "There is nothing like unto Him" [Q. 42:11]. ${ }^{88}$ The mistake of the Ash'arīs here, he argues, is that they effectively deny those attributes that they consider ambiguous because they cannot but understand them in a way that befits created beings. He thereby turns the accusation around, implying that it is actually the Ash'aris themselves who are guilty of anthropomorphism - a classical Hanbali counterargument we may note, that was also utilized by Ibn Taymiyya. ${ }^{89}$ Furthermore, al-Wāsițī points to the fact that the Ash'arīs do affirm seven basic attributes of God, namely, life (hayāt), hearing (sam), sight (bașr), knowledge ('ilm), power (qudra), express will (iräda), and speech (kalām). ${ }^{90}$ He argues that, even though any of these could be understood as an accident ('arad) that exists in a corporeal body, they do affirm these as attributes in a way that befits God. To this he objects that

it is not fair that they are only able to understand [God's] sitting, descent, face, and hand as attributes of created beings and thus feel the need to interpret [them] metaphorically and alter [their meanings]. For if that is how they understand these attributes, that should compel them to [also] understand the seven attributes [that they do affirm] as attributes of created beings resulting from accidents! ${ }^{91}$

If the Asharīs reply that the seven attributes are certainly not accidents but apply to God in a way that befits Him, al-Wāsițī replies that, likewise, God's sitting on the Throne applies to God without limitation (hașr) but in a way that befits Him..$^{92}$

87 Miftāh al-ma'rifa wa-al-ibāda, p. 26o; Miftāh țarīq al-muhibbīn, p. 279; al-Sirr al-mașūn, pp. 55-56; Risāla fì ithbāt, p. 44; 'Umdat al-țullāb, p. 211.

88 Al-Wāsițī, Qā'ida fì dhikr asbāb al-mahabba, p. 57; Wașiyya, p. 140.

89 Al-Wāsițī, Risāla fì ithbāt, p. 44. For Ibn Taymiyya, see Hoover, Ibn Taymiyya's Theodicy, p. 5o. For an example of an earlier Hanbalī authority who used this argument, see: Muhammad b. al-Ḥusayn b. al-Farrā' Abū Ya'lā (d. 458/1066), Ibțāl al-ta’wìlāt li-akhbar alșifāt, ed. Abū 'Abd Allāh Muḥammad b. Ḥamad al-Maḥmūd al-Najdī (Maktabat Dār alimām al-Dhahabī, 199o), pp. 45 \& 49.

9o Al-Wāsițī, Risāla fí ithbāt, p. 44. These seven basic attributes can be traced back to alAsh'arī himself, who considered belief in them to be one of the fundamental theological truths, cf. Frank, "Elements in the Development," p. 154.

$91 \quad$ Al-Wāsițī, Risāla fì ithbāt, p. 45.

92 Al-Wāsițī, Risāla fì ithbāt, p. 45; 'Umdat al-țullāb, p. 204. 
As a consequence of having embraced the traditionalist position against $t a^{\prime} w \bar{l} l$ in favor of $i t h b \bar{a} t$, the nuṣuss now offered al-Wāsiți a considerable number of divine names and attributes that he would hitherto have rejected as such. This naturally meant that whatever his former Ash'arī-Sufi colleagues had claimed of ma'rifa of God was by reason of their theological affiliation incomplete and deficient. It is therefore that al-Wāsiți often emphasizes the gravity of the aforementioned rule, that a sound creed is a condition for one's sulük. As a firm traditionalist, it was his understanding that any mistake in this discipline will have dire consequences for one's knowledge of God.

\subsection{The Critical Importance of Direction}

Here, we must take note that, within the subject of the sifät, the previous example of God's position vis-à-vis His creation (His aboveness and elevation and sitting on the Throne) is repeated most frequently by al-Wāsiți in relation to ma'rifa. Without a doubt, he considered this the most important aspect of creed that ought to be verified by knowledge and assent (tașdīq). ${ }^{93}$ That is so, he states, because it serves as the foundation (așl) and basis (asās) for the sălikin and their starting point of spiritual knowledge (mabda' al-ma'ārif). ${ }^{94}$ He therefore puts in extra effort to convince his audience of the necessity to affirm these as attributes of God. Fully aware of the heated debates on the matter (especially from the side of the Ash'aris, as noted above), he admits that the sălik may initially be reluctant to do so out of fear that God is thereby restricted by direction, which would violate His transcendence. ${ }^{95} \mathrm{He}$ argues that its correctness can nonetheless be confirmed based on both revelation and reason, and that to do so is imperative for one's further sulük, as we shall soon see.

When it comes to the Qur'an and the hadìth literature, al-Wāsiți tries to demonstrate on numerous occasions that they are filled with evidence for his creedal position on this matter. He cites at least fourteen verses that, in his opinion, support the reality of God's aboveness and elevation - such as: "They fear their Lord above them (min fawqihim)" [Q. 16:50] - and he cites two verses in support of God's sitting on the Throne - such as: "The All-Merciful, sat on the Throne ('alā al-'arsh istawā)" [Q. 20:5]. ${ }^{96}$ As for proofs from the hadīth

93 Al-Wāsițī, Miftāh al-ma'rifa, p. 261; 203; al-Sirr al-mașūn, p. 55.

94 Al-Wāsițī, Miftāh al-márifa, p. 261; 'Umdat al-ṭullāb, pp. 203 \& 205; al-Sirr al-mașūn, p. 55; Madkhal ahl al-figh, pp. 53-54; Qāida fì al-umūr al-muwașșila, p. 218.

95 Al-Wāsițī, Risālatuhu ilā al-shaykh al-Maghribī, p. 108.

96 The Qur'anic references to fawqiyya given by al-Wāsițī are: Q. 3:55, 4:158, 6:18, 16:50 \& 102, 35:10, 40:36-37, 67:16-17, 70:3-4, and 87:1. The Qur'anic references to istiw $\bar{a}$ ' are: Q. 10:3 and 20:5. See: al-Wāsițī, Risālatuhu ilā al-shaykh al-Maghribī, pp. 104-105; 'Umdat al-țullāb, pp. 204-205; Miftāh al-ma'rifa, p. 26o; Risāla fì ithbāt, p. 27. 
literature, he often refers to a report popular among traditionalists, wherein the Prophet asks a slave girl where God is, to which she replies that He is in heaven $(f \grave{\imath} a l-s a m \vec{a})$ while pointing towards the sky. The Prophet then validated her answer and rejected none of it, al-Wāsițī adds. ${ }^{97}$ His argumentation also draws from the well-known tale of the heavenly journey, the mira $\bar{a}$, during which the Prophet reportedly ascended through the seven heavenly spheres until he reached a distance of two bows or less from God. This, too, is in his eyes a clear confirmation that God exists over His creation. ${ }^{98}$

While such proofs would have sufficed for the classical traditionalist, alWāsiți also deploys logic to defend his position against the accusation of attributing limitation to God. This approach was perhaps inspired by his master, Ibn Taymiyya, himself an advocate of harmonizing reason and revelation. There is, however, some irony in the fact that to absolve God from any limitation by direction and space, our Iraqi Sufi turns to a typical Ash'arī argument. He first tries to solve the supposed contradiction between God's transcendence and the attributes of aboveness and sitting by admitting that it would indeed be unbelief and anthropomorphism to assert that God is restricted and enclosed by any direction, or that He is carried by any place: "He [God] was and there was nothing with Him in His antiquity and pre-eternity"99 (kāna wa-lā shay' ma'ahu fi qidamihi wa-azaliyyatihi). God existed before the creation of boundaries (hudūd) and directions (jih āt), and since nothing new befalls Him in His essence or His attributes, "He is now as He was (huwa al-än kamā kāna)."100 If we refer to chapter 2, we may recall that the words "He was and there was nothing with Him" were actually taught to al-Wāsiți as a fundamental spiritual maxim by his Shādhilī shaykh, Najm al-Dīn al-Ișbahānī, in relation to the vanity of self-direction (tadbir). We may also recall that the notion of God's preeternity was similarly used by the Ash'arī-Shādhilī Sufi Ibn al-Labbān to denounce literal aboveness as a divine attribute, arguing that God is now as $\mathrm{He}$ was without any direction and, consequently, without aboveness. It thus seems that al-Wāsițīs line of reasoning against limitation and anthropomorphism

97 Al-Wāsițī, Risālatuhu ilā al-shaykh al-Maghribī, p. 104; 'Umdat al-țullāb, p. 205, Risāla fì ithbāt, pp. 40-41.

98 Al-Wāsițī, Miftāḥ al-márifa, p. 26o; Risāla ilā al-shaykh al-Maghribī, p. 108; 'Umdat alțullāb, p. 205, Risāla fì ithbāt, p. 27.

99 Al-Wāsițī, Risālatuhu ilā al-shaykh al-Maghrib̄̄, p. 109.

100 Al-Wāsițī, Risālatuhu ilā al-shaykh al-Maghribì, p. 109; Risāla fì ithbāt, p. 41, where he says that, before the creation "God was and there was no place, Throne, water, space, air, void,

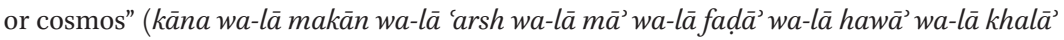
wa-lā malä'). 
here may actually be adapted from his knowledge of Shādhilī doctrine rather than Ibn Taymiyya's formulation of traditionalist theology.

Having acquitted himself of tashbih, our Iraqi Sufi proceeds to make his argument for fawqiyya and istiwa $\bar{a}$ ' as follows. He states that when God's express will (iräda) decreed the existence of creatures restricted by direction, who by necessity require aboveness, underness, rightness, and leftness, He decreed that they exist in locality (mahall). ${ }^{101}$ Being created in this fashion,

the judgment of [God's] magnificence of lordship (hukm 'azamat alrabbāniyya) required that He be above His kingdom, and that the kingdom be under Him - which is in terms of the temporality (al-hudūth) inherent to the creation, not in terms of the pre-eternity inherent to the Creator. So when I refer to Him, it is impossible that this be done by a downward direction, a right direction, or a left direction. Rather, it is only fitting to refer to Him by the direction of elevation ('uluw) and aboveness (fawqiyya). Again, such reference is from the viewpoint of [created] existence, its temporality, and its downward direction. ... When this is known, then [understand that] sitting $($ al-istiw $\vec{a})$ [too] is an attribute of Him that existed in His antiquity ( $f_{\imath}$ qidamihi), although its property only manifested upon the creation of the Throne, in the same way as the reckoning (hisāb) is a pre-eternal attribute of Him whose property will only manifest in the Afterlife. ${ }^{102}$

Al-Wāsitị thus assumes that the only appropriate mode of existence for the creation is in a downward direction (jihat al-taht); God directs us from above, ever remaining unbounded by any physical boundary or restriction as He has always been in His pre-eternity. This he connects to the Qur'anic verse "Surely your Lord is God, Who created the heavens and the earth in six days, then sat on the Throne, directing the affair" [Q. 10:3]. ${ }^{103}$ Due to mankind's reality as temporal, created beings bounded by direction and space, we can never truly comprehend the notion of 'directionlessness' (ghayr-jihāt), al-Wāsițī argues. We therefore refer to God by fawqiyya, the highest part of the created realm as we understand it, because it is the most appropriate point of reference for Him. ${ }^{104}$ When the sălik understands this, he will know that there is no anthropomorphism in affirming fawqiyya and istiw $\bar{a}$ : "Whoever verifies this in his

\footnotetext{
101 Al-Wāsițī, Risāla fì ithbāt, pp. 40-41; Risālatuhu ilā al-shaykh al-Maghribū, p. 109.

102 Al-Wāsițī, Risāla fì ithbāt, p. 41.

103 Al-Wāsițī, Risālatuhu ilā al-shaykh al-Maghribī, p. 109; Risāla fì ithbāt, p. 41; Riḥla, p. 46.

104 Al-Wāsițī, Risālatuhu ilā al-shaykh al-Maghribī, p. 109.
} 
creed firstly, then in his spiritual taste (dhawq) and unveiling (kashf) secondly, his heart will be freed from the resemblance [it has] to attributing limitation [to God] and the discomfort experienced at referring to the direction [of aboveness]."105

Although al-Wāsiți considered this sufficient as an explanation, if we further inquire into his reliance on traditionalist cosmology, we may better grasp how he really understood God's existence in literal aboveness, seated on the Throne. As he puts it, there is a boundary where the created realm stops and God's mode of existence without directions (jihät), distances (masāfät), boundaries (hudūd), and dimensions (aqțār) starts: "[God] is bounded by a boundary (hadd) that distinguishes His magnificence and essence (dhät) from all that He created." ${ }^{106}$ God does not become part of the creation's restrictions by entering it - which would be incarnation $(h u l \bar{u} l)$ - but is rather ever separate $(b \bar{a} \imath i n)$ from it. Our Iraqi Sufi thus differentiates between existence inside the created world (dākhilal-'ālam) and existence outside of it(khārijal-'ālam).107 The former applies to creatures, the latter to God. From the viewpoint of human beings existing inside the created world, it would require an ascension from earth through the seven heavenly spheres to reach the boundary of 'the outside,' al-khärij, which starts from God's Throne. What lays beyond the Throne neither reason nor imagination can comprehended, for it is the unfathomable reality where God exists in His essence. ${ }^{108}$ In other words, the only way to reach the realm where space and direction cease to exist is to go upwards, and it is from there that the creation located under it is governed by God.

Why is this so important to al-Wāsiți? In full acknowledgment of mankind's limited nature, he holds that we are inherently in need of a qibla: a direction to face towards during our acts of worship. That is so, he argues, "because we are temporal beings (muhdathün), and a temporal being cannot get around direction when it turns itself towards [God]."109 And since the revelation makes it very clear that God exists in an upwards direction from the viewpoint of His creation, that should naturally be our qibla. ${ }^{110}$ However, most Sufis literally miss the mark here, he says, due to their disavowal of aboveness:

\footnotetext{
105 Ibid.

106 Al-Wāsițī, Risāla fì ithbāt, p. 41.

107 Al-Wāsițī, Wașiyya, p. 143; Miftāḥ al-márifa, p. 261; Risāla fì ithbāt, p. 42.

108 Al-Wāsițī, Risāla fì ithbāt, pp. 41-42.

109 Ibid. p. 49.

110 Al-Wāsițī, 'Umdat al-țullāb, pp. 204-205; Qācida fì al-umūr allatīyanbaghī an takūn hamm al-sālik, p. 197; Wașiyya, p. 142; al-Sirr al-mașūn, p. 55; Madkhal ahl al-figh, pp. 53-54; Risāla fì ithbāt, p. 49.
} 
More numerous are those who deviate from spiritual realization (tahqi $q$ ) due to their ignorance in this regard. Indeed, I found that the majority of the sālikin and seekers I have come across do not have a qibla that they turn themselves towards, because they have not verified that their Lord is above all things, separate from His creation, and are thus confused about this. Among them are those who believe that there is no 'inside' to the [created] world nor an 'outside,' that it has no 'above,' nor an 'under,' and among them are those who say that [God] is everywhere. It is certain that their hearts will never reach the reality of this affair ....

Hence, the foremost concern of the truthful ones (al-șädiqin) is their ma'rifa that their Lord is above all things. For those among them who acknowledge this, it becomes their heart's qibla whenever they direct themselves towards Him and supplicate Him, in the same way as someone who performs the ritual prayer takes the Ka'ba as his qibla when he prays: he turns himself in its direction, and this is of the same nature [as turning towards the Throne]. Now, when the aspiring seeker (al-tălib almurid) becomes certain of this, the Throne becomes his heart's qibla whenever he turns himself towards God and desires Him, and it will be from this elevated place (al-mahall al-ulwī) [of the Throne] that blessings descend upon him and the realities of divine openings (futūhāat) are revealed to him - by the will and volition of God!111

Evidently, al-Wāsițī envisioned the heart's qibla being upwards as more than a mere direction to focus on during worship. For him it is the only way to become connected to the Throne, which he considers the required gateway to God for one's further sulük. The sālik should therefore aspire to have his heart constantly directed upwards in all deeds performed for the sake of God, so that it ultimately becomes connected to the Throne. By doing so, he states in a letter: "The heart ascends upwards (ilä al-uluw), one heavenly sphere after another, until it ends up at the Throne. When it ends up at the Throne, directions, distances, limits, and dimensions are nonexistent, and all that remains is $\mathrm{He}$ who has no likeness and is not restricted by any limit."112

What becomes clear from the above is that the role of fawqiyya in al-Wāsiți's Sufism leaves no room for any other theological denomination to lay claim to ma'rifa. In his view, only the adherents of the Ahl al-Sunna - which we know he considers a synonym for the Ahl al-Hadith - can make the Throne into their

111 Al-Wāsițī, Miftāh al-ma'rifa, pp. 261-262. A very similar description is given in 'Umdat al-țullāb, p. 204.

112 Al-Wāsițī, Risālatuhu ilā al-shaykh al-Maghrib̄̄, p. 112. 


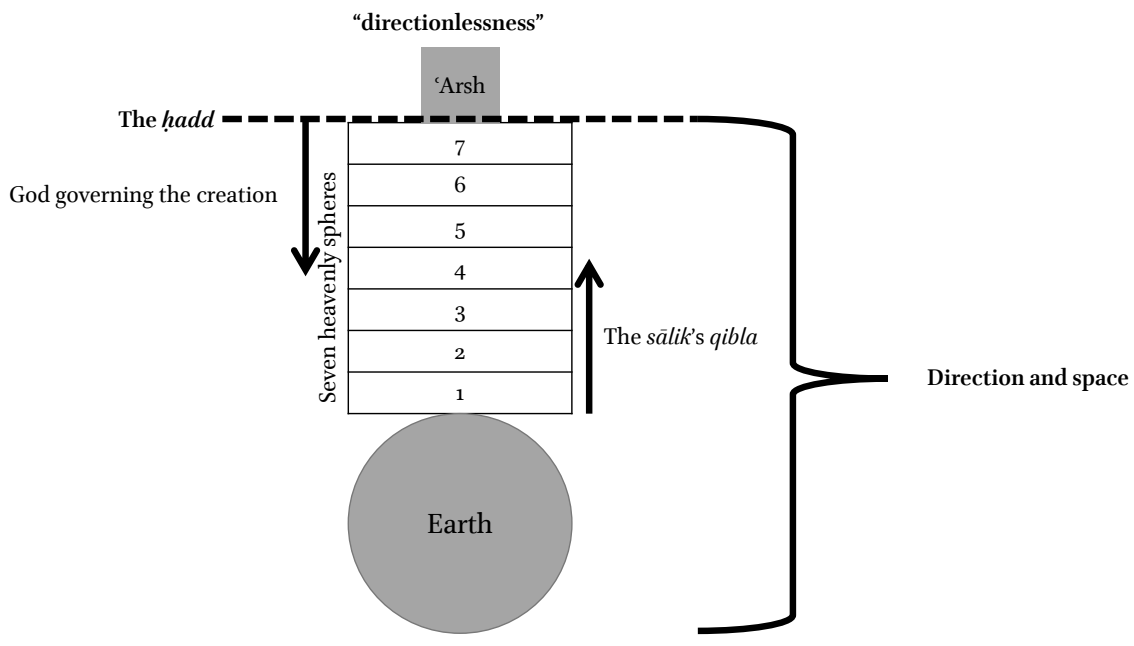

FIGURE 20 A schematic representation of al-Wāsițīs traditionalist Sufi cosmology. Compiled by the author

hearts' qibla, whereas those who strip God of His attributes (ahl al-tațill) a typical traditionalist label for the Ash'aris - are unable to experience this. In light of that, his mention of the sālikin who fail to verify God's aboveness in the earlier quote will surely have been chiefly directed at those who ascribe to the Ash'arī school. He contests that, although they may know God by such attributes as hearing, sight, and pre-eternity, their ma'rifa is incomplete because they remain lost in their ignorance of the direction of their object of worship. ${ }^{113}$

After the sālik has acquired a sound theological understanding of the divine attributes, the next step of ma'rifa in al-Wāsițîs Sufism is to recite the Qur'an and reflect on it as if hearing it directly from its original Speaker (min mutakallimihi) from above the Throne. While the sâlik would previously only recite the Qur'an for the sake of God, he now ascends to a degree in which he perceives God's Self-manifestations (tajalliyyāt) in the words of revelation through the divine names and attributes. ${ }^{114}$ For the time being we must pause here, as it is from this point that al-Wāsițīs doctrine takes the sālik from theory to practice by means of his acquired ma'rifa of the attributes, ultimately leading to what

113 Al-Wāsițī, Risāla fì ithbāt, p. 49; Wașiyya, p. 142.

114 Al-Wāsițī, Qã̄ida fì mazāhir al-shuhūd wa-al-ma'rifa, p. 140; Q̄̃̄ida fì dhikr asbāb al-ma-

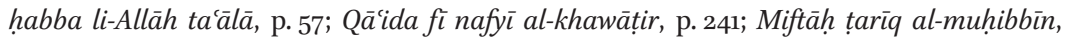
pp. 280 \& 283; Miftāh al-márifa, p. 265. 
he calls 'the witnessing of divinity,' mashhad al-ilähiyya, a degree in his sequence of sulük that belongs in the next chapter.

What this tells us is that while the current section has led us through a complex set of theological principles that may at first sight appear to have little to do with Sufism, al-Wāsitị envisioned them as the very basis from which the sălik proceeds to traverse the required degrees of witnessing (mashähid) that should eventually lead to the apex of the spiritual path. Thus, if we were able to recognize a distinctly traditionalist, nușuṣs-based spirituality in the previous section on the Muhammadan way, then this is all the more so when it comes to his treatment of ma'rifa of God. Not only does it revolve around basing one's knowledge of God solely on the Qur'an and the Sunna - that is, "knowing God as He describes Himself" - but it actually leans directly on the notion that adherence to the traditionalist creed is an essential requirement for one's sulük. Without affirming all of God's attributes from the nușuṣ, one falls short in ma'rifa of Him; and without affirming the literal meanings of God's aboveness and sitting on the Throne, one is left worshipping God without direction, and it becomes impossible to connect one's heart to God's Throne.

It isn't hard to fathom that such a traditionalist approach to the concept of ma'rifa will have met with the approval of Ibn Taymiyya and the members of his circle. I would therefore argue that the teachings of al-Wāsitị we have analyzed in the present section should be understood against the background of their shared activism for the traditionalist cause. His doctrine of ma'rifa sets an unmistakable course for a full rejection of any kalāmī - and especially Ash'arī - inspired form of Sufism, a topic we will further elaborate upon in the following section.

\section{What Sufism is Not: Refuting the Deviations of Sufis}

The misconception that Ibn Taymiyya saw no place for Sufism in Islam is still surprisingly strong today. For the most part, this is because much of his written effort on the subject was aimed at attacking and refuting those practices and/ or doctrines of Sufis which he thought contradict the original religion of the Prophet. From his perspective, however, rather than refuting tașawwuf, he was cleansing it of incorrect and heretical notions by pointing out what Sufism is not, or should not be. ${ }^{115}$ Occasionally, his pupil al-Wāsiți displays a similar attitude in the polemical side of his writings. While he certainly never reaches

115 It has been said that this is in fact Ibn Taymiyya's approach to religion in general: to show what Islam is by pointing out what Islam is not. See for instance: Bazzano, "Ibn Taymiyya, 
the depth and intensity of his master's polemics, we can find many examples where he tries to argue what true Sufism is by 'othering' those interpretations he disagrees with.

It will not come as a surprise that his critiques in the field of Sufism are conditioned by his experiences described in the previous three chapters. We will therefore focus on the three most significant recurring issues from his polemics, according to the chronological order of his journey. We will start with his refutation of $s a m \bar{a}^{c}$, the Sufi audition, which he often connects specifically to the Rifā̄iss. Then, following on from the Ash'arī-traditionalist divide discussed in the previous section, we turn to al-Wāsițî's staunch opposition to the influence of philosophy and kalām on Sufism. Here, special attention will be given to an isolated instance where he expresses harsh criticism towards Abū alḤasan al-Shādhilī, the eponymous founder of the Shādhiliyya. Finally, we turn to his most fierce polemics, which are reserved for Ibn 'Arabī and his followers, whom he regarded as the most dangerous Suf group in his age. Throughout these topics, I will occasionally make note of the overlap he displays with the spirit of Ibn Taymiyya's polemical thought. As stated before, this is not to prove that he was necessarily directly influenced by him or copied his arguments, but rather to stress once more that he was working from the same Ahl al-Hadith framework as his shaykh. In the conclusion to this chapter, we will discuss how al-Wāsițī's polemics may be linked to our analysis of the tarīqa Muhammadiyya and ma'rifa of God.

\subsection{SufiAudition (Samāc)}

Although al-Wāsițī had found that $\operatorname{sama}^{c}$ was also practiced by the Sufis of Baghdad and the Akbarians of Cairo, he was evidently most troubled by the manner in which it manifested amongst the fuqară $\bar{a}^{\prime}$ of the Rifā'ī order of Wāsit and its surroundings. ${ }^{116}$ There are several instances in his writings where he cautions against $s a m \bar{a}^{c}$ by specifically calling attention to their practice of the ritual, which he clearly considered its most extreme form. ${ }^{117}$ That this was no

Radical Polymath. Part 2," p. 119. I have also made note of this in my article, Post, "A Glimpse of Sufism," p. 162.

116 In the previous chapter I have made no mention of the $s a m \bar{a}^{c}$ amongst the Akbarians, as al-Wāsițīs primary focus in his account on them is not their practice but rather their doctrine. He does, however, refer to their sama $\bar{a}^{c}$ in his Rihla, p. 42, where he says that "to them, the $s a m \bar{a}^{\mathrm{r}}$ is the most desirable thing that incites their impulses, during which spiritual knowledge of non-delimited existence (ma'ärif al-wujūd al-muțlaq) is aroused."

117 al-Wāsițī, Wașiyya, pp. 145; Mīzān al-shuyūkh, p. 244-245; and possibly in Qã ída fí ítibār ahl al-khayr wa-ghayrihim, pp.134-135. In Qã ida mukhtașara, p. 38 it is clear that, although he does not explicitly name the Rifāiiyya, his description of those who perform sama $\bar{a}$ ' is without a doubt in reference to them. He states: "we ought to cry over ourselves, 
trivial matter, in his view, is evident from his Mīzān al-shuyūkh, where he puts forth the same characteristic descriptions of their sama $\bar{a}^{c}$ rituals that we have come across in his autobiographical account in chapter 1: They are once more depicted as innovators who dance during $s a m \bar{a}^{c}$, allow men and women to associate with one another, and eat live snakes and other forbidden things. AlWāsiți then testifies by God that if the Prophet, the first four caliphs, the emirs of the Companions, or the Umayyads would see them in such a state, "they would call them to God; and if they'd refuse, they would wage holy war against them (jähadūhum) with their swords ..."118 Although this statement is not solely directed at the Rifấi $s a m \bar{a}^{c}$, he considered this particular issue to be at the heart of many of the immoralities he saw them practice under the guise of Sufism.

Needless to say, the $s a m \bar{a}^{c}$ was a matter that he found deserving of critical attention, perhaps even more so because it was such a widespread practice among the Sufis of his age. It is likely that his critical attitude resonated well with the community of traditionalists in early Mamluk Damascus, among whom there probably existed something of a general dislike towards the practice. The Hanbalī master Ibn Qudāma al-Maqdisī had already issued a fatwa against it, and Ibn Taymiyya also launched attacks against it in several of his writings. ${ }^{119}$ In his aim to keep Sufism compatible with traditionalism, al-Wāsițī may thus have regarded it as something of an obligation to formulate why, from the perspective of a Sufi, sama $\bar{a}^{c}$ has no place in the pure Sufism of the Muhammadan way. This he tries to do, above all, in al-Bulgha wa-al-iqnā fi hall shubhat mas'alat al-sama $\bar{a}^{c}$ (The Sufficiency and Convincement to Solve the Obscurity on the Issue of $S a m \bar{a}$ ), a treatise dedicated solely to the subject. We will therefore go through his main arguments found therein, and supplement it with references from his other writings that are of relevance.

for we are tested today by [Sufi] groups (țawäiff) who concern themselves with eating what is forbidden .... They lay claim to spiritual states, but they do not smell the distinguished flavor of Islam in their exterior, nor the penetrating flavor of faith in their interior. They perform auditions (samā $\bar{a} t)$ and dance to it the entire night, and when they perform the ritual prayer they peck like crows!" The last words concern the act of bowing in the Muslim ritual prayer, and indicate that they hastily perform the prayer. Note that in his Rihla, p. 18, al-Wāsiți describes the Rifāciyya in very similar words.

118 Al-Wāsițī, Mīzān al-shuyūkh, p. 246.

119 For Ibn Qudāma's fatwa, see his Dhamm mã 'alayhi mudda'ū al-tașawwuf (Beirut/Damascus: al-Maktab al-Islāmī, 1983). For Ibn Taymiyya, see MF, vol. 11, pp. 557-586 and pp. 587649 for two fatwas against samā'; he also deals with the topic in his al-Tuhfa al-Irāqiyya fi al-a'māl al-qalbiyya, ed. Yahyyā b. Muḥammad b. 'Abd Allāh al-Hunaydī (Riyad: Maktabat al-Rushd, 200o), pp. 430-443. 
First, it is interesting to note that al-Wāsițī was able to see why one could easily be confused regarding the impermissibility of $s a m \bar{a}^{c}$. He clearly appreciates some of the effects the $s a m \bar{a}^{c}$ may have on its listener, admitting that it is not altogether void of good. He writes, for instance, that one's inward being (al-bäțin) can be positively affected by the melody, vocals, and tones of the beautiful, spiritual poems that are recited. This may aid in casting out concern for all that is not God (al-aghyār) and put to rest distracting whispers (wasāwis), ease the carnal soul (nafs), and stimulate the heart in what it requires of spiritual states $(a h w \bar{a} l)$ such as love for God (mahabba), longing for Him (shawq), intimacy with Him (uns), and nearness to Him (qurb). ${ }^{120}$ On top of that, alWāsiți acknowledges that Muslim scholars differ on the legal status of the $s a m \bar{a}$. Some jurists hold it to be permissible, while others hold it to be forbidden. Even among the Sufis, he says, there are some of the later knowers of God (al-ärifin al-muta'akhkhirin) who practiced it, some who did not, and still others who used to do it and then later repented from it. ${ }^{121}$

His own verdict is simply that the evil of sama $\bar{a}^{c}$ outweighs its good, and that this is why it was never ordered by the Prophet. If the performance of $s a m \bar{a}^{c}$ would increase us in virtue and nearness to God, or if it would be a path towards God's contentment, then the Prophet would not have concealed it from us, he argues. The truth of the matter is that it does result in evil, such as unlawful love, unlawful assemblies, and unlawful gazing. Under the pretext that it is a gathering of the pious it becomes, in the end, a gathering of the corrupt. ${ }^{122}$ For the most part, this depiction of the effects of sama $\bar{a}^{c}$ appears to be based on what he himself claims to have observed during the sessions of the Rifāiss, wherein handsome young boys and women would supposedly participate, as seen in chapter 1.

In the knowledge that $\operatorname{sam}^{\mathrm{c}}$ was not prescribed by the Prophet nor by the first four caliphs, al-Wāsiți makes it plain that it is essentially an innovation (bid'a). Going for the typical Hanbali argument, he stresses that we ought to be on our guard against innovations, since the Prophet said that "every newly invented thing is an innovation (bid'a), every innovation is an error, and every error belongs in the hellfire."123 He believes that this is also why it would not be sufficient to defend sama $\bar{a}^{c}$ on the basis of its acceptance by some of the wellknown Sufis. He simulates a discussion on the matter as follows:

\footnotetext{
120 Al-Wāsițī, al-Bulgha, f. 64b and 66a.

121 Al-Wāsițî, Mas'alat fi al-samāc , The National Library of Israel, JER NLI AP Ar. 158/7: f. 62b.

122 Al-Wāsițī, al-Bulgha, f. 66b-67a.

123 Al-Wāsițī, al-Bulgha, f. 67a. This well-known hadìth can be found in: Abū 'Abd al-Raḥmān Aḥmad b. Shu'ayb al-Nasā'ì, al-Sunan al-șughrā, ed. 'Abd al-Fattāḥ Abū Ghudda (Aleppo: Maktab al-mațbū'āt al-Islāmiyya, 1986), vol. 3, p. 188.
} 
Someone may argue: This $s a m \bar{a}^{c}$ was practiced by a group of the friends [of God] (awliy $\left.\bar{a}^{\prime}\right)$ whose high station with God we do not doubt, such as the generations of Sufis [sic] of Junayd and his companions, al-Shibli and his like, Yūsuf b. al-Ḥusayn al-Rāzì, and those before him such as Dhū alNūn al-Mișrī, and others like them. Then how can it be acceptable to us that you disregard them?

It is said [in response]: Even if it was practiced by a thousand renunciant, worshipful, pious individuals - or more or less [than that] - it has still been omitted by the generality of the Companions of the Messenger of God (Ṣ), and they were on intimate terms with him! If Dhū al-Nūn had [indeed] done it, then it was still omitted by Abū Bakr al-Ṣiddīq. Or even if it was attended by Junayd, it has been established on his own account that he repented from the $s a m \bar{a}^{c}$ and renounced it before he passed away. ${ }^{124}$

As we have noted before, a core aspect of al-Wāsițīs sulūk is the premise that the religion is perfectly complete as it was taught by the Prophet, and that there is no need to go beyond the nuṣuṣ. Just as this applies to the way God describes Himself in the revealed texts, this also holds true for the rituals of worship by which one means to draw closer to God. Based on this premise, alWāsiți holds that there are no grounds for practicing the kind of $s a m \bar{a}^{c}$ that involves dancing, singing, and the beating of drums, since neither the Prophet nor the Companions ever did this. ${ }^{125}$

He does offer an alternative, however, by differentiating between two types of $s a m \bar{a}^{c}$. On the one hand, there is the variety we have thus far been discussing, for which he says the word 'sama $\bar{a}^{\circ}$ has become the technical term agreed upon by the people of his age, thus labeled 'al-samā' al-isțilăhï.'126 On the other hand, there is the variety that is rightful by the revelation, thus labeled ' $a$ samā'al-mashrü.' He argues that it ought to be realized that the former variety is made up of doubt (shubha) and worldly appetite (shahwa). Doubt, he explains, is the uncertainty concerning the truth of what one experiences during the $s a m \bar{a}$ 'gathering, as the references to God's love in the poetry that is recited therein may at times lead one to find a share of the spirits (nașīb al-arwāh h). Worldly appetite, on the other hand, is the share of the carnal souls (nașīb alnufüs) that is intermingled with the share of the spirits, which eventually causes the $s a m \bar{a}^{c}$ to become something that is done for the Devil rather than for God. As for the rightful samác, in accordance with the covenant ('ahd) of

124 Al-Wāsițī, al-Bulgha, f. 67a.

125 Al-Wāsițī, Mìzān al-shuyūkh, p. 244.

126 Al-Wāsițī, Mas'alat fì al-samā', f. 62b, where he says: "isțalaḥa 'alayhi ahl hādhā al-zamān." 
the Prophet, the rightly guided caliphs, and the Followers (tābi inn), that is to listen closely to the Qur'an. As opposed to samā' ișțilāhī, al-Wāsiți holds that this variety is purely for the spirit, so that neither the carnal soul nor the Devil can have a share in it. ${ }^{127}$

He then tries to demonstrate that the two varieties of $s a m \bar{a}^{c}$ are in truth irreconcilable by highlighting the essential differences between them. He states that those Sufis who practice samác iștilāḥi supposedly argue that the Qur'an does not behoove the innate nature of man (țibä al-bashar), so that one will not find ecstasy (wajd) when listening to its audition. They are said to believe that poetry does behoove man and softens the heart, so that one ought to listen to that instead. ${ }^{128}$ As to be expected, al-Wāsițī rejects this as a vile argument, stating that as a consequence of this erroneous claim, such Sufis are unable to find any spiritual sensation - or dhawq, 'taste,' as he calls it - in the recitation of the Qur'an (tilāwa) and the ritual prayer (șalät):

The realizers (muhaqqiqūn) have verified that the taste of $s a m \bar{a}^{c}$ conflicts with the taste of ritual prayer. Hence, anyone who is enraptured during the samác iștilāhī and finds therein the perfection of his taste will not find the taste of Qur'anic recitation and ritual prayer. In all likelihood, the one who tastes sama $\bar{a}^{c}$ will never find the taste of ritual prayer, because there is a conflict between these two tastes that is known by those who know the distinguished taste of Islam. ${ }^{129}$

By the word 'realizers' al-Wāsiți likely means the true Sufis, those who have attained to haqiqa, the deeper, spiritual reality of things. He continues his argumentation, emphasizing how curious it is that the hearts of some Sufis who claim to love God have no room for the sama $\bar{a}^{c}$ of God's Speech, and are instead filled with the $s a m \bar{a}^{c}$ of poetry and hand-clapping. ${ }^{130}$ As we have alluded to in the previous section, he holds that it is in the Qur'an that the sälik finds tajalliyya $\bar{t}$ : those verses wherein God manifests Himself to His servants through His divine names and attributes. He therefore considers it essential to listen attentively to the recitation of God's verses and reflect on their meanings, as they are a gateway to intimate knowledge of Him (ma'rifa). ${ }^{131}$

Such is, in his view, the only true and rightful $s a m \bar{a}^{c}$ as practiced by the Salaf and the righteous Sufis of old and, as such, a trademark of those who stick to

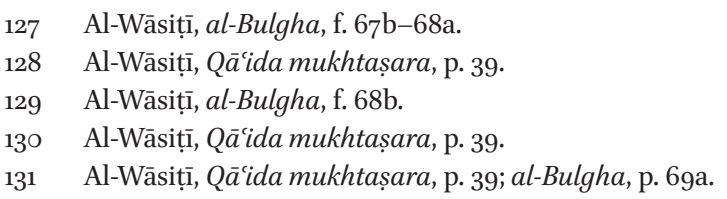


Muhammadan poverty (ahl al-faqr al-Muhammadī). ${ }^{132}$ He claims that among those who adhered to it were Fuḍayl b. 'Iyāḍ, Ibrāhīm b. Adham, Wahb b. alWard, Wahb b. al-Munabbih, Ḥudhayfa b. al-Mar'ashī, Sufyān al-Thawrī, Dhū al-Nūn al-Mișrī, Shaqīq al-Balkhī, Ḥātim al-Așamm, Sahl al-Tustarī, Ma'rūf alKarkhī, Sarī al-Saqațī, Abū al-Qāsim al-Junayd, and others like them. ${ }^{133}$ In laying claim to these names, he creates the image that the $s a m \bar{a}^{c}$ that is rightful by revelation was in fact part of the tradition of the early models of authentic Sufism, sadly abandoned by the majority of the later Sufis.

Interestingly, Ibn Taymiyya has the exact same argumentation concerning $s a m \bar{a}$. He, too, differentiates between what he views as the newly invented $s a m \bar{a}^{c}$ of the later Sufis and the Qur'anic sama $\bar{a}^{c}$. Likewise, he claims that the latter variety of $s a m \bar{a}^{c}$ was originally practiced by the very same list of early Sufi authorities also mentioned by al-Wāsițī. ${ }^{134}$ Although such arguments may very well predate both Ḥanbalī scholars, I have yet to find earlier examples wherein Qur'anic sam $\bar{a}^{c}$ is similarly linked to the first generation of the Sufi figures. If this notion was actually brought into being by either al-Wāsiṭi or Ibn Taymiyya, it remains impossible to say whether one had appropriated the arguments of the other, or whether they simply shared a method that coincidentally led to the same conclusions on this issue.

\subsection{Philosophy and Kalām}

Moving on to the second object of al-Wāsițī's polemics, he held that the majority of the fallacies and heresies he found in the words and deeds of his fellow Sufis can be traced back to foreign influences that entered Islam. He names the books of the ancient philosophers (al-falāsifa) and sages (al-hukamä), in particular, as the main source of deviation that slowly poisoned the pure religion (al-sharîa al-khālișa) by inspiring the establishment of such sciences as logic (manțiq) and speculative theology (kalām) within the domain of Islam. ${ }^{135}$ Again, he leans on the traditionalist premise that the pathway unto God can only be known by what God Himself has revealed, so that the faculty of reason (quwwat al-'uqūl) should not be allotted any role therein. Because God was the source of knowledge for the Prophets, only they proclaimed absolute truths, he contends. The philosophers, on the other hand, rely on reason, which can be flawed. Therefore, he argues that in its utter perfection and completeness,

132 Al-Wāsițī, Qāiida mukhtaṣara, pp. 39-40.

133 Al-Wāsițī, Mìzān al-shuyūkh, p. 245.

134 Ibn Taymiyya, $M F$, vol. 11, p. 592; and also his al-Tuhfa, pp. 430-431 \& 439-440.

135 Al-Wāsițī, 'Umdat al-țullāb, p. 202. 
God's religion should not be intermingled with sciences that are the product of mankind's own reasoning. ${ }^{136}$

He claims, however, that this is exactly what many Muslims have done since they have gradually turned to kaläm. He places the beginning of this development around the third and fourth century after Hijra, not long after the end of the age of the Salaf, we may note. ${ }^{137}$ In Talqĭh al-asrär, he specifically names the reign of the 'Abbāsid caliph Abū Ja'far Abd Allāh al-Ma'mūn (r. 198-218/813833 ) as the turning point from which the religion began to become weak and disunited. Now, al-Ma'mūn was the caliph responsible for instigating the famous Mihna, the inquisition known especially for enforcing the doctrine that the Qur'an is created, which was officially adopted by the 'Abbāsid caliphate. Since this Mihna was perhaps the greatest clash between the rationalist partisans of kaläm and the traditionalist partisans of hadith, it is unsurprising that al-Wāsițī mentions this particular caliph when he speaks of what he views as the decay of pure religion. It is often disregarded that this episode did not revolve solely around the createdness of the Qur'an, but also meant to censure the traditionalists' affirmation of the apparent meanings of the ambiguous descriptions of God from the nușuș, which was considered anthropomorphism from the kalämı point of view. The Mihna resulted in the persecution and flogging of the eponymous founder of al-Wāsițìs own madhhab, Aḥmad Ibn Hanbal, and demonstrated more clearly than ever before that the mutakallimün were a force to be reckoned with. ${ }^{138}$

I have argued several times before that, although never stated explicitly, alWāsițî's allusions to the presence of kalām theology in the religious landscape of his own context would, above all, have been made in relation to the Ash'arīs. ${ }^{139}$ They had by then become the most authoritative mutakallimūn in Sunni Islam, having triumphed over practically all opposing theologies of the other kaläm schools. ${ }^{140}$ In Miftāh țaríq al-awliya $\bar{a}$, al-Wāsiți even directly admits that the true traditionalists have become a minority in his age when he adjures his

136 Al-Wāsițī, Hayāàt al-qulūb, p. 74 .

137 Al-Wāsițī, Risālatuhu ilā al-shaykh al-Maghribī, p. 105; Wașiyya, p. 139.

138 On the clash between rationalism and traditionalism during the Mihna, and Ibn Hanbal's story in that regard, see for instance: Nimrod Hurvitz, "Mihnna as self-defense," Studia Islamica, no. 92 (2001): pp. 93-111; Christopher Melchert, "The Adversaries of Ahmad Ibn Hanbal," Arabica 44:2 (1997): p. $25^{2}$.

139 Speaking of kalām in his age, al-Wāsițī mentions how the kind of $t a$ 'wül we have treated in the previous section has come to dominate Muslim theology. This, as we have noted, was also the position of a branch of the Ash'arīs. See his Risālatuhu ilā al-shaykh al-Maghribī, p. 105; Wașiyya, p. 139.

140 Makdisi, "Hanbalite Islam," pp. 220 \& 228; Ignaz Goldziher, Introduction to Islamic Theology and Law (Princeton: Princeton University Press, 1981) pp. 94-95. 
reader to follow the jurists, fuqarä, and Sufis of the Ahl al-Sunna wa-al-Hadith, "who base themselves on the science of hadith and athar," and adding that "they are but few." ${ }^{141}$

When it comes to Sufism, he holds that the majority of the Sufi masters of old would have adhered to the traditionalist creed, and that kaläm - again, most likely in the form of Ash'arism - only infiltrated the ranks of the later ones. Among the early traditionalist Sufis who would have affirmed God's aboveness he specifically names al-Muhāāibī, al-Tustarī, 'Amr b. 'Uthmān al-Makkī, al-Junayd, and perhaps surprisingly, al-Ḥakīm al-Tirmidhī, a proto-Sufi reproached by Ibn Taymiyya on several occasions. ${ }^{142}$ Among the increasingly rare examples of traditionalist Sufis from the generations that followed after them al-Wāsițī only names 'Abd Allāh al-Anșārī and 'Abd al-Q̨ādir al-Jīlānī, both Hanbalī Sufis we may recall. ${ }^{143}$

A noteworthy observation is that while he is frequently critical of the influence of kaläm on later Sufism, he hardly ever sees the need to do so in connection to any particular individual or group. One of the rare instances where he attaches a name to his criticism is an isolated mention of Abū al-Qāsim alQushayrì (d. 465/1072), whom he says "would fanatically cling to the school (madhhab) of those who make ta'will and negate direction," a remark that is clearly directed at al-Qushayrì's Ash'arī affiliation. Apart from al-Qushayrī, I have only found him explicitly mention kalām in relation to the Shādhiliyya.

Despite his claimed dislike for kalām well before his entry in Damascus, his changing views on the Shādhiliyya after he had settled there suggest that his

141 Al-Wāsițī, Miftāh țtarīq al-awliyà̃ , p. 35 .

142 Al-Wāsițī, Risālatuhu ilā al-shaykh al-Maghribī, p. 108, where he says that "even al-Hakīm al-Tirmidhī - may God have mercy on him - states in his writings that the hearts ascend to the heavens, until they eventually end in al-malaq, which is a place in the Throne where the hearts of the friends [of God] who have reached nearness are suspended: they are the gathered hosts of them, the ones set above the others." This shows that al-Wāsitị was probably familiar with al-Tirmidhì's famous Sirat al-awliy $\bar{a}^{\prime}$ (better known as Kițab khatm al-awliy $\bar{a}^{\prime}$ ), a book that was severely criticized by Ibn Taymiyya (see for instance: $M F$, vol. 11, pp. 373-382). Compare al-Wāsițîs quoted words with the critical edition of Sìrat al-awliyā', in: al-Ḥakīm Muhammad b. 'Alī al-Tirmidhī, Thalāțat muṣannafāt li-alHakìm al-Tirmidhī, ed. Bernd Radtke (Beirut/Stuttgart: In Kommission bei Franz Steiner Verlag, 1992), p. 18; and in translation, see: Bernd Radtke \& John O'Kane, The Concept of Sainthood in Early Islamic Mysticism: Two Works by al-Hakim al-Tirmidhï; an Annotated Translation with Introduction (Richmond, Surrey: Curzon Press, 1996), p. 68; Interestingly, on pp. 64-65 Radtke also makes note of al-Tirmidhì's more traditionalist hadith-based understanding of Islamic cosmology, which he says had not yet been influenced by the ancient Greek philosophical world model.

143 Al-Wāsițī, Risālatuhu ilā al-shaykh al-Maghribī, pp. 107-108; Madkhal ahl al-figh, pp. 5153 . 
comments in censure of rationalist theology within the domains of Sufism were to some degree influenced by his membership of Ibn Taymiyya's circle. Clearly, his stance towards his fellow Sufis became more and more defined in accordance with the principles of traditionalism as he lived amongst the Taymiyyans. In chapter 2 we have already seen that he had addressed his disappointment with the Shādhilīs' reliance on kalām quite carefully in his autobiography; for although he strongly disapproved of it, he still found much good in their spiritual teachings. However, his attitude is markedly different in Qā'ida fi așnäf al-ta'alluh. In this treatise he states that there is in some ways a distance between the Shādhilī way and the Muhammadan way, only known to those who know the tariqa Muhammadiyya. His main argument against the Egyptian Sufi țăifa is that al-Shādhili had "associated with the sciences of the philosophers ('ulüm al-falāsifa), because he refers to the universal intellect (al'aql al-kullī) in his discourse."144 Al-Wāsiți then goes on to say that whoever attaches himself to the Moroccan shaykh will therefore be molded by some precepts that are correct, and some that are not.

We may perceive this change of tone as an indication of his increasingly hardened stance towards non-traditionalist Sufis. As we have noted in chapter 3 , this occurred against the background of his growing rigor in adhering to the principles of traditionalism from the moment he had settled in Damascus onwards. This left no room for elements that were not in some way based on the $n u s ̦ u s$, at least from his point of view. It seems that, more than before, traditionalist theology had become the balance to measure which Sufis were part of the Ahl al-Sunna and which ones were not, and thus ought to be avoided.

There is reason to believe that Ibn Taymiyya's teachings played some role in this development. The Ḥanbalī shaykh al-Islām displays a very similar outlook on the influence of philosophy and kalām on Sufism in his writings. Like alWāsițī, he claims that the early Sufis belonged to the Ahl al-Hadìth and affirmed all of God's names and attributes. And again, apart from al-Hakīm al-Tirmidhī, he names the exact same authorities to give examples of Sufis he accepts as traditionalists. Only among the later shaykhs does he start to distinguish roughly between two categories of deviating Sufis: those who were influenced by the kalām theology of the Jahmiyya, such as the Ash'ari Sufi al-Qushayrī and his ilk, and those who were influenced by Greek philosophy, such as the Sufis of Ibn 'Arabī's school of ittihād.145

144 Al-Wāsițī, Qā'ida fì aṣnāf al-ta’alluh, p. 151.

145 Ibn Taymiyya, Kitāb al-șafadiyya, vol. 1, p. 267; Dar' ta'ārud, vol. 5, pp. 4-7, vol. 6, p. 266, vol. 7, p. 145; al-Radd' 'alā al-Shädhilī, p. 39. 
The influence of Ibn Taymiyya on al-Wāsiți in measuring Sufism according to the balance of traditionalism was likely also what caused the latter's change of heart regarding the Shādhiliyya. In fact, he may have borrowed the abovementioned argument against al-Shādhilī from his Hanbalī master. Although relatively unknown, Ibn Taymiyya composed a refutation of the Moroccan Sufi, which goes into considerable detail to censure some statements of his in the field of Sufism. The second half of the book deals exclusively with a lengthy passage quoted from a treatise that is attributed to al-Shādhilī, wherein the latter makes mention of the primordial intellect (al-'aqlal-așlì) and the necessary intellect (al-'aql al-darūrì). ${ }^{146}$ Ibn Taymiyya, who was without a doubt much more knowledgeable in philosophy than al-Wāsițī, then goes to great lengths to show that these two terms originate from philosophy and have nothing to do with the pure religion of the Prophets. What is interesting is that, contrary to al-Wāsițīs claim, to my knowledge the eponymous founder of the Shādhiliyya never uses the term 'universal intellect' (al-'aql al-kullī) in the writings attributed to him. However, commenting on the two intellects that are indeed mentioned by al-Shādhilī, Ibn Taymiyya says in his refutation that the philosophers view 'the active intellect' (al-'aql al-fa ' $\bar{a} l$ ) as the intellect that is closest to us "and [that] they say that the scriptures that came down unto the hearts of the Prophets come from it, and that [God's] words that reached Moses came from it."147 In other words, Ibn Taymiyya apparently understood one of the terms used by al-Shādhilī as a reference to the 'active intellect.' Because the 'universal intellect' mentioned by al-Wāsițī and the 'active intellect' mentioned by Ibn Taymiyya happen to be synonymous, it becomes very plausible that the former may have taken his argument against al-Shādhilī from the latter. ${ }^{148}$ If this is indeed the case, then we have here another clear indication that al-Wāsiți’s hardening attitude towards Sufis who did not operate strictly within the boundaries of traditionalism was, at least to some degree, influenced by Ibn Taymiyya. Whether the same can be said of our next and final topic, his polemical activity against the Akbarian Sufis, is not so clear-cut as we will now see.

\footnotetext{
146 Ibn al-Ṣabbāgh, Durrat al-asrār, p. 134.

147 Ibn Taymiyya, al-Radd' 'alà al-Shādhilī, p. 132.

148 While al-'aql al-kullī is more commonly known as al-'aql al-fa'call, its use can be traced back to the Brethren of Purity (ikhwān al-șafä), see for instance: Ismail K. Poonawala, "Humanism in Ismāìīi Thought: The Case of the Rasā̉il Ikhwān al-Ṣafă’ (The Epistles of the Sincere Brethren and Faithful Friends)," in Universality in Islamic Thought, ed. M. Morony (London: I. B. Tauris, 2014), p. 71.
} 


\subsection{The Monistic Akbarians}

Based on our study in the previous chapter, it appears that al-Wāsițīs severe animosity towards the monism (waḥda), unification (ittiḥa d), and incarnation ( hulül) supposedly professed by the Akbarians had sprung forth from his own experiences among them in Cairo rather than under the influence of Ibn Taymiyya's polemics. It remains difficult to assess whether the latter's writings and arguments against their teachings did inspire the refutations al-Wāsiți subsequently composed himself against the Akbarian school, as there certainly are parallels that can be drawn between them. However, it is also true that Ibn Taymiyya is much more elaborate in his argumentation, and also delves into philosophy when discussing Ibn 'Arabī and his doctrine, a field al-Wāsițī never really quite dares to engage with. ${ }^{149}$ I have not found the latter ever bring up philosophy in relation to the Akbarians, whereas we have noted above that his Hanbalī shaykh specifically linked the roots of monistic Sufism to it. This, I would argue, indicates that the arguments al-Wāsițī sets forth in refutation of Akbarian Sufis were rather the fruits of his own labor.

It is important to note that by far the bulk of his polemical effort in the field of Sufism is directed against Ibn 'Arabī and his followers. He authored at least three refutations that deal solely with the heresies he found in their doctrine, two of which have been at my disposal. These are: Lawāmi al-istirshād fi alfarq bayna al-tawhīd wa-al-ittihād (Flashes of Guidance to Differentiate Between Divine Unity and Monism) and Ashi'at al-nuṣuṣ fi hatk astār al-Fuṣūṣ (Rays of Statements to expose 'the Fușūs'). ${ }^{150}$ The former is meant as a rather elementary and general warning against monistic Sufism, while the latter is specifically written as a step-by-step rebuttal of Ibn 'Arabī's treatise Fuṣūṣ alhikam. Besides these two titles and the section on the Akbarians from alWāsițīs autobiography, there are at least seven more works that contain passages in which he attacks them and their teachings. ${ }^{151}$

149 Below I will give a summary of al-Wāsițī's argumentation against the Akbarians. For Ibn Taymiyya's detailed refutation of them, see for instance his Haqüqat madhhab al-ittihādiyyin, in $M F$, vol. 2, pp. 134-284.

150 Unavailable to me has been al-Bayān al-mufìd fì al-farq bayna al-ittihäd wa-al-tawhìd (The Beneficial Elucidation on the Differentiation between Monism and Divine Unity), which al-Wāsițī mentions in Risālatuhu ilā al-shaykh al-Maghribī, p. 114. Note that I have consulted two editions of Ashi'at al-nușūs, one of which is published in al-Imādiyyāt (pp. 5385). The other edition is published under the variant title Bāshürat al-nușūs fì hatk astār al-Fușuss and misses certain words and phrases found in the former, which sometimes make the text less clear. I have therefore chosen to rely on the former rather than the latter.

151 Talqüh al-afhām, pp. 152-153; Lawāiḥ min qawāid, pp. 124-128; al-Tadhkira, pp. 35-36; Miftāh al-ma'rifa, p. 253; Risālatuhu ilā al-shaykh al-Maghribī, pp. 113-117; 'Umdat alțullāb, pp. 214-215; Qā'ida fì bayān al-sulūk, p. 163. 
Below will follow a summary of the main arguments directed against them and the doctrine of wahdat al-wujüd, the unity of being. In the previous chapter we have already been given a taste of al-Wāsitịis problem with the latter concept, which revolves around the Akbarian conception of existence in relation to God's unity. However, since his autobiographical account does not convey the full depths of his argumentation, there is still more to be said in that regard.

If one undertakes to study what it is al-Wāsițī says about Ibn 'Arabī and his followers in his other writings, it soon becomes apparent that his most vicious slander is directed against them. This should not come as a surprise, as we have seen that of all the Sufi groups he had come across he was evidently most troubled by them. We may thus presume that, as with the subject of $s a m \bar{a}^{c}$, he saw it as something of a necessity to distance himself and the science of tașawwuf from their doctrine in unequivocal terms - and this he indeed does. He displays no reluctance to openly declare that those with Akbarian leanings are outside the pale of Islam, and on several occasions even calls upon God to eradicate them from the face of the earth. ${ }^{152}$ In one letter, he argues that it is forbidden to say the customary invocation for a deceased Muslim, "may God have mercy on him," after mentioning the names of Ibn 'Arabī, Ibn Sabīn, alQūnawī, Ibn Hūd, al-Balyānī, al-Tilimsānī, and their ilk. ${ }^{153}$ At times, their deviant nature is emphasized by comparing their heresy to that of the Bătiniyya and Qarāmița Shi'ites, and by linking their doctrine to the eponymous founder of the Jahmiyya, Jahm b. Safwān (d. 128/745), and to the Murji'î theologian Bishr b. Ghiyāth al-Marīīi (d. 218 or 219/833 or 834 ). ${ }^{154}$

It would nevertheless be wrong to assume that al-Wāsițī's treatment of the Akbarians does not surpass mere name-calling. As we have seen in the previous chapter, he appears to have become well familiar with Ibn 'Arabì's madhhab (school or doctrine) when he stayed in Cairo. This is indeed substantiated by his analysis of their teachings as found throughout his writings.

Because he was convinced that anyone who desires to know the true doctrine of Ibn 'Arabī should consult the Fușūs al-hikam, the majority of his polemical attention is devoted to this book. ${ }^{155}$ When he brings forward proofs for what he considers the heresy in Akbarian teachings, he almost exclusively does so by referring to or quoting from the Fușuss. A typical example is the following passage from his Ashicat al-nușūṣ:

\footnotetext{
$15^{2}$ Al-Wāsițī, 'Umdat al-țullāb, p. 214; Ashi'at al-nușūṣ, pp. 30 \& 58.

153 Al-Wāsițī, Risālatuhu ilā al-shaykh al-Maghribì, p. 113.

154 Al-Wāsițī, Lawāmi', p. 94; Talqüh al-afhām, p. 153.

155 Al-Wāsițī, Risālatuhu ilā al-shaykh al-Maghribì, pp. 114.
} 
O people of intelligence, ponder over these words and you will understand their intent; [Ibn 'Arabī] says [in the Fușūṣ al-ḥikam]: "[God] is your mirror in which you see yourself ..." Do you understand what this means? It means that, since His essential existence emanated upon you, He is like a mirror in which you see that your immutability in non-existence exists. Thus, the existence of the Real is your mirror in which you see yourself.

Then he says: "... and you are His mirror in which He sees His names and perceives their properties (ahkām)." This means that if you did not exist, His names would not be manifest. Hence, you are a mirror for Him, so that His names can manifest, in the same way as $\mathrm{He}$ is your mirror in which you yourself manifest. 156

In al-Wāsițîs view, such lines from the Fușuṣ he quotes here perfectly exemplify what the doctrine advocated by Ibn 'Arabī entails. Let us therefore elaborate on this passage.

In his introduction to Ashi"at al-nuṣuṣ, al-Wāsiți tells us that the Akbarians believe that existents only come into being after God's essential existence (wujūdahu al-dhātī) emanates upon what they call either 'quiddities' (māhiy$y \bar{a} t$ ) or 'concrete things' ( $a^{\prime} y \bar{a} n$ ). These are immutably fixed in non-existence (thäbitat ${ }^{a n} f i$ al-'adam) until they receive existence through this emanation (fayd) in accordance with their predisposition (istic $d \bar{a} d$ ) to do so. This, the Akbarians are said to believe, is the only way they become existents. When this occurs, God's own existence enters the perceptible realm (fi al-zähir), in which the properties (ahkām) of His names and attributes then manifest. ${ }^{157}$ These names and attributes are not other than Him, but in truth identical with Him. Hence, unity (wahda) becomes manifest in multiplicity (kathra) without thereby becoming manifold, as God's essence ever remains one. As an example, al-Wāsițī considers a creature that is granted provision, 'al-marzūq' in Arabic. He explains that the Akbarians would say that this creature remains immutably fixed in non-existence until God's existence emanates upon it. Only then can it be perceived as al-marzu $\bar{q}$, whereby God's divine name alRazzāq, the Provider, simultaneously becomes manifest. According to our Iraqi Sufi, the Akbarians hold that this Self-manifestation of God (al-tajalli ) is motivated by His desire to become acquainted with Himself through Himself, since

156 Al-Wāsițî, Ashicat al-nușūs, p. 63. A very similar analysis of the same passage from the Fuṣuṣs is provided by al-Wāsițī in his Risālatuhu ilā al-shaykh al-Maghribī, p. 116.

157 In Ibn 'Arabī's terminology, the properties (ahkām, sing. hukm), refer to "the ruling power or the governing control of the divine names in the cosmos," cf. Chittick, The Sufi Path of Knowledge:Ibn Al-'Arabi's Metaphysics of Imagination (State University of New York Press, 1989), p. 39 . 
$\mathrm{He}$ is able to see Himself in the quiddities/concrete things at the moment $\mathrm{He}$ reveals Himself to them. ${ }^{158}$

Al-Wāsițī observes several elemental problems here, which, in his view, contradict the very tenets of Islam. First, if the quiddities/concrete things only receive existence from God in accordance with their predisposition, that would mean that they have a degree of free disposal, independent of God. While God may decide to emanate existence or not, He has no choice when it comes to the measure in which they are predisposed to receive it from Him. Second, if nothing of His existence emanates on them, that would mean that He has no name or attribute in a state of manifestation at all, so that, as a consequence, He becomes something non-delimited (muțlaq) without existence. Third, if God is dependent on them for His Self-manifestation, that would mean He is in need of them - for whoever is sustained by something is in need of it. As long as they do not receive existence from Him, neither God's own existence nor His names and attributes manifest in the perceptible realm. In that sense, they are thus His source of sustenance. The same goes the other way around: The quiddities/ concrete things are in need of God for their existence, for without it they remain non-existent, immutably fixed in their non-existence. Hence, as al-Wāsițī understands it, Akbarian doctrine comes down to the notion that there is a mutual dependency here: God serves the creation, and the creation serves God. ${ }^{159} \mathrm{He}$ argues that this is in complete disagreement with the doctrine of the Muslims, according to which God's essence and His names and attributes are in continuous existence since pre-eternity. There is nothing newly added to God by what is brought forth from what He creates that has not already been a part of Him in His pre-eternity. God's creation, on the other hand, only comes into being by His will and is ever utterly dependent on its Creator. ${ }^{160}$

In Lawāmic al-istirshād al-Wāsiți explains that the roots of this heresy are deviation from the traditionalist premise of upholding the way God describes Himself and not going beyond what the nușuṣs explicitly state. It is in essence due to the Akbarians' exaggeration in affirming God's unity (al-tawhìd) that they have ended up practicing what al-Wāsiți calls the worst form of polytheism. He contends that while the polytheists of the pre-Islamic era (al-jähiliyya) ascribed equals to God by worshipping false idols, stones, stars, trees, and other similar vile objects of worship, the Akbarians actually make all existents into associates with God by affirming that they are identical with Him. To them,

\footnotetext{
158 Al-Wāsițī, Ashi“'at al-nușūs, pp. 57-58; Talqūh al-afhām, pp. 152-153; Lawā̉iḥ min qawā'id, pp. 124-126; Risālatuhu ilā al-shaykh al-Maghrib̄i, pp. 114-115.

159 Al-Wāsițī, Ashicat al-nușūṣ, pp. 58-6o; Talqüh al-afhām, pp. 152-153; Lawā̉ih min qawāid, pp. 124-126; Risālatuhu ilā al-shaykh al-Maghribì, pp. 114-115.

16o Al-Wāsițī, Ashi“'at al-nușūṣ, p. $5^{8}$ and again on p. 81.
} 
"every created thing is a locus of manifestation in which the Real manifests with His very essence (bi-haqiqatihi) and [in which] He discloses Himself with His existence and 'I'-ness (bi-wujüdihi wa-aniyyatihi). They thereby reach the essential meaning of polytheism."161 With this doctrine, al-Wāsițî says, it becomes possible to assert that worshipping idols is in reality no different from worshipping God, something Ibn 'Arabī himself actually dared to utter in the Fușūss, he points out. ${ }^{162}$ Such beliefs come down to incarnation and unification (al-hulül wa-al-ittihăd) - although, he acknowledges, the Akbarians themselves would deny that, saying that for one thing to become incarnate in something else requires duality; and this can never be the case as everything is one in their view. ${ }^{163}$

While for al-Wāsiți the heresies inherent to this doctrine were apparent, he still felt it posed a very real threat to the Muslim community due to its strong potential to misguide people through its manipulation of allusions ('ibārāt) and terminology of the true Sufis from among the Muslims (șüfyyat ahl alIslām). His genuine concern appears to have been that if those who are heedless of the objectives of the Akbarians hear such teachings as related above, phrased in the language of the Sufis, they may think that it refers to the Sunni creed of tawhìd and the truthful witnessing of God's actions (shuhüd al-af'äl) to which the Sufis allude. That, he says, is because their words resemble the actual truth, namely, that everything in existence only exists by God's express will. ${ }^{164}$ In Lawäih min qawā id ahl al-zaygh he sketches the following picture to exemplify how people may be misguided by Akbarian teachings:

If someone from them studies these [Akbarian] fundamentals (qawāid), writes them down, believes in them, and then enters a spiritual retreat (khalwa) with an empty belly, invoking God with the profession of His unity for some time, ${ }^{165}$ it will not take long before this illusion (wahm) [of wahdat al-wujüd] becomes strong in him. It is very well possible that he becomes deluded by it through a state that hits him, or some inspiration (wārid) that comes over him. He will then depart from his retreat, imagining that he has become reality itself, saying: "glory be to me!"166

\footnotetext{
161 Al-Wāsițī, Lawāmic, p. 93; Post, "A Taymiyyan Sufi's Refutation," p. 320.

162 Al-Wāsițī, Ashi“'at al-nuṣūs, 67.

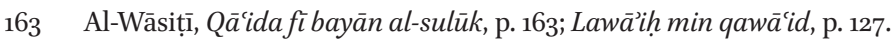

164 Al-Wāsițī, Lawāmic pp. 95-96; Lawā̄ị min qawā'id, p. 124.

165 Literally: “... invokes 'there is no deity but God' for some time" (wa-yadhkuru "lā ilāha illā Allāh" muddat $\left.{ }^{a n}\right)$.

166 Al-Wāsiṭī, Lawā̄ị̣ min qawā'id, p. 127.
} 
What al-Wāsitī speaks of here is what he regards as an example of the way Akbarians manipulate the Sufi concept of annihilation in God $\left(\right.$ fan $\left.\bar{a}^{\prime}\right)$, and render it into a spiritual state of intense awareness of the unity of existence. Hence the expression "glory be to me!" which is actually meant in glorification of God, in their eyes is the only true reality of existence. He contends, however, that "this is not the fana $\bar{a}$ of the lovers [of God] from the Sufis (al-muhibbin min alsüfyya), who are annihilated through the One they love so that they become absent from their own 'selves."'167 But, he concludes, someone who is not aware of the Akbarians' heresy will not be able to differentiate between their fan $\vec{a}^{\text {' }}$ and that of "the folk of truth."168

With this line of argumentation, al-Wāsiți once more differentiates between true Sufis and impostor Sufis. Leaning on the notion that the true Sufis acted in accordance with the principles of traditionalism, and were indeed themselves traditionalists, Ibn 'Arabī and his followers are by reason of their monistic doctrine automatically excluded from their ranks. He makes the same point in Lawāmi`al-istirshād, where he writes:

We, the people of reason, should not exceed the tawhid that [God] has made plain to us, but only seek intimate knowledge [of Him] (ma'rifa) by means of what He has revealed to us. We should not be greedy in seeking tawhìd and adopt everything as a divinity, thus exaggerating in the confession of His unity. By acknowledging that only God has existence we would be making Him identical with everything. We would thereby fall into religious laxity and neglect the obligations, pertaining to what is forbidden and what is permitted, break down the barrier of the revealed law, and exceed the guidance of those who preceded us from our Prophet's Companions and the shaykhs of our [Sufi] community (țäifatinā ), such as Sahl [al-Tustarī], al-Junayd, al-Sarī [al-Saqaṭī], 'Amr b. 'Uthmān [alMakkī], Abū Sa'̄ìd al-Kharrāz, Ibn 'Ațā', and their generations. ${ }^{169}$

The aim of this passage is, of course, to belittle the Sufi credentials of the Akbarians by laying claim to several of the same respected early Sufi authorities we have come across in the previous discussions on samā' and philosophy. AlWāsiṭi alludes to these Sufis as 'țẩifatinā' to single them out as representatives of traditionalist Sufism, who, in his view, never dared to profess the likes of

167 Al-Wāsițī, Risālatuhu ilā al-shaykh al-Maghribī, p. 117.

168 Al-Wāsițī, Lawāì min mawā'id, p. 126.

169 Al-Wāsițī, Lawāmic', p. 96; Post, "A Taymiyyan Sufi's Refutation," pp. 324-325. 
wahdat al-wujüd. He thereby once more tries to emphasize the 'otherness' of Ibn 'Arabī and his followers.

\section{5 Conclusion}

As we have now reached the final word on al-Wāsițīs polemics against Akbarian doctrine, our concluding topic, it will be useful to briefly reflect on the pattern we may recognize throughout the sections of the present chapter in order to tie them all together. As a general observation, we can say that we have been able to discern a distinct presence of Hanbali traditionalism in each of the subjects that we identified as one of the foundations of al-Wāsițìs Sufism. It is therefore not unfitting to speak of it as 'al-sulūk al-atharī', the traditionalist spiritual way, as it was called by Ibn Rajab. This is a label our Iraqi Sufi in all likelihood would not have been unappreciative of.

To start at the beginning, in the first section of this chapter we found that al-Wāsițī spoke of his way of sulūk as the tariqa Muhammadiyya to highlight that he envisioned it as being based solely on the inner dimension of the Prophet's Sunna. Therefore, rather than connecting spiritually to any Sufi shaykh, he taught a method of spiritually connecting to the Prophet's incorporeal being, which could be established through one's love for him on the basis of intimate knowledge (ma'rifa) of his life and times. Thus, the first foundation of his Sufism was primarily a textually based method that revolved around a close study of the nușuss in order to become acquainted with the Prophet and his Companions. The second foundation was very similar in that it also started with a close study of the nușuss, only this time to gain ma'rifa of God and connect to Him by becoming intimately acquainted with Him "as He describes Himself" in the revelation. For al-Wāsițī, this could only be reached through a traditionalist understanding of what the nușuṣ say regarding the divine names and attributes, especially when it comes to God's aboveness and sitting on the Throne. Thus, the second foundation of his Sufism was first and foremost a matter of studying the descriptions of God from the Qur'an and the Sunna in accordance with the traditionalist creed.

This reliance on traditionalist theology was also the common thread in his polemics. We have seen that, whether it concerned the practice of $s a m \bar{a}^{c}$, the presence of philosophy and kalām in Sufism, or Akbarian doctrine, he considered them all illegitimate on more or less the same grounds. In his view, they all lacked any explicit basis in the texts of the Qur'an and the Sunna, so that their existence essentially depended on deviation from the nușuṣ. Of course, what constitutes deviation is in the eye of the beholder, and the way al-Wāsiți 
circumscribed it depended heavily on his adherence to the theological framework of traditionalism as he understood it. With regard to his polemics, it is also significant to note that he repeatedly laid claim to several, widely respected Sufi masters to lend credence to his traditionalist vision of Sufism. He thereby aimed to effectively highlight the 'otherness' of those practices and doctrines he polemicized against by disassociating such well-known, and often legendary, shaykhs from them.

As a final observation, we may notice that al-Wāsițī and Ibn Taymiyya not only had very similar concerns when it came to the state of Sufism in their age, but also shared a common approach to address the problems they perceived therein. Their shared effort to filter Sufism of what they saw as deviations, and their utilization of a very similar language to do so, is not so much an issue of the authoritative influence of one over the other, as it is a matter of group identity. For both of them, their outlook on Islam was anchored in the tradition of the Ahl al-Hadith, or perhaps more accurately, in their specific image and understanding of this tradition. I would therefore argue that we should see the similarities between them in light of the traditionalist activism that we have noted in the previous chapter as a characteristic element of the Taymiyyan jama $\bar{a} a$ - a cause Ibn Taymiyya strove for as the group's leading jurist and theologian, and al-Wāsițī, evidently, as the group's leading authority in the field of Sufism. 